UN Use of Private Military and Security Companies: Practices and Policies

Åse Gilje Østensen 
SSR PAPER 3

\section{UN Use of Private Military and Security Companies \\ Practices and Policies}

Åse Gilje Østensen 
Published by

Ubiquity Press Ltd.

6 Osborn Street, Unit 2N

London E1 6TD

www.ubiquitypress.com

Text @ Åse Gilje Østensen 2011

First published 2011

Transferred to Ubiquity Press 2018

Cover image (c) Rick Bajornas/UN Photo

Editors: Alan Bryden \& Heiner Hänggi

Production: Yury Korobovsky

Copy editor: Cherry Ekins

ISBN (PDF): 978-1-911529-30-9

ISSN (online): 2571-9297

DOI: https://doi.org/10.5334/bbn

This work is licensed under the Creative Commons Attribution 4.0 International License (unless stated otherwise within the content of the work). To view a copy of this license, visit http://creativecommons. org/licenses/by/4.0/ or send a letter to Creative Commons, 444 Castro Street, Suite 900, Mountain View, California, 94041, USA. This license allows for copying any part of the work for personal and commercial use, providing author attribution is clearly stated.

This book was originally published by the Geneva Centre for the Democratic Control of Armed Forces (DCAF), an international foundation whose mission is to assist the international community in pursuing good governance and reform of the security sector. The title transferred to Ubiquity Press when the series moved to an open access platform. The full text of this book was peer reviewed according to the original publisher's policy at the time. The original ISBN for this title was 978-92-9222-181-2.

SSR Papers is a flagship DCAF publication series intended to contribute innovative thinking on important themes and approaches relating to security sector reform (SSR) in the broader context of security sector governance (SSG). Papers provide original and provocative analysis on topics that are directly linked to the challenges of a governance-driven security sector reform agenda. SSR Papers are intended for researchers, policy-makers and practitioners involved in this field.

The views expressed are those of the author(s) alone and do not in any way reflect the views of the institutions referred to or represented within this paper.

Suggested citation:

$\emptyset$ stensen, Å. G. 2018. UN Use of Private Military and Security Companies: Practices and Policies. London: Ubiquity Press. DOI: https://doi.org/10.5334/bbn. License: CC-BY 4.0 


\section{Contents}

Introduction

Defining private military and security companies 6

Filling a knowledge gap 8

The United Nations and PMSCs: An overview

Direct versus indirect UN use of PMSCs 12

PMSCs in UN humanitarian operations 14

PMSCs in peacekeeping operations 15

PMSCs in political missions 17

UN demand for PMSC services

Security and protection services 20

Peacebuilding support services 29

Mission support services 36

UN policies on the use of PMSCs

Safety and security perspectives 40

Humanitarian perspectives 43

Peacekeeping perspectives 49

Procurement perspectives 54

Human rights perspectives 58

Conclusion 



\section{INTRODUCTION}

In recent years influential member states have urged the United Nations (UN) for greater efficiency, often calling for market-oriented solutions. As a result, the United Nations has increasingly expanded and intensified its relationship with the private sector. ${ }^{1}$ The trend is illustrated by a rapid scaling up of public-private partnerships and increased outsourcing of tasks in most entities of the UN family. Testimony to this trend, the UN Office for Project Services (UNOPS), which conducts procurements for a wide range of UN projects, for the first time in 2009 reported spending more procuring services than goods. ${ }^{2}$ The provision of security services is not exempt from these developments. Accordingly, private military and security companies (PMSCs) are among the many commercial partners of the United Nations.

PMSCs form part of a growing transnational market for force which exists alongside, and is intertwined with, governmental and intergovernmental actors. The existence of such companies is not a new phenomenon, but it is a lesser known fact that some of them have been present in most UN operations since the 1990s. Indeed, some companies have a history of working with the United Nations which dates back decades. Of late, the private military and security industry increasingly offers services that penetrate some of the core activities and tasks of the United Nations and is eager to supplement the tasks often performed by UN organisations in humanitarian and peacekeeping operations, political missions or as part of regular country office work. The practice of the United Nations buying PMSC services is, however, rarely a topic open to discussion, and there has been little public acknowledgement of it whatsoever. The controversial nature of the issue appears to have 
prevented the formulation of a coherent political and practical approach to PMSCs among UN bodies. It also seems to have contributed to an ad hoc contracting culture in contrast with other goals set by the organisation.

Recently, the prospect has emerged that issues and dilemmas linked to PMSC deployment can be addressed more openly. In early 2011 the UN Department of Safety and Security (DSS) initiated the development of a policy proposal which offers recommendations for more responsible and coherent PMSC contracting practices. ${ }^{3}$ Whether the initiative, once it has been finalised, will in fact resonate and be welcomed throughout the multifaceted organisation is yet to be seen. Nevertheless, placing the issue on the agenda is crucial, as the lack of coherence and consistency across the UN system regarding this politically very sensitive issue could create several problems for the organisation, including damage to UN legitimacy, legal liability issues, additional risks to the United Nations and its personnel within operating environments and weakening perceptions of UN impartiality. The current incoherence could also not only serve to securitise or militarise operations, but may encourage concealment of a practice which urgently needs international political discussion. ${ }^{4}$

Whether PMSCs constitute a menace or a blessing has been a matter of contentious debate. This paper does not discuss the potential contribution of PMSCs to peace, security or other UN objectives. Instead, it looks at how some parts of the UN system make use of these companies and tries to trace the demand to internal and external challenges. Furthermore, the paper addresses whether there are established guidelines or policies governing PMSC use in different parts of the organisation, whether practices comply with them, or if PMSCs are used more as ad hoc 'band-aids' in response to extreme operating environments. In this process, the paper also looks into where in the UN organisational system, and based on what credentials, decisions to hire PMSCs are made. Hopefully, this will elucidate some of the different perspectives of PMSC contracting and their rationales.

\section{Defining private military and security companies}

Several different labels have been used to describe the array of diverse companies addressed in this paper, including 'private security companies', 'military provider firms', 'corporate mercenaries', 'private defence services 
providers', etc. The industry itself has often resorted to somewhat euphemistic labels such as 'security management companies' or 'risk mitigating companies'. Alternatively, they avoid labels and simply describe their services. Taking this tendency into account, the 2008 Montreux Document on pertinent international legal obligations and good practices for states related to operations of private military and security companies during armed conflict identifies PMSCs as 'private business entities that provide military and/or security services, irrespective of how they describe themselves'. ${ }^{5}$ The international Code of Conduct for Private Security Providers (ICOC), which is a related Swiss initiative for enhanced regulation of the private security industry, refers only to private security companies and private security providers, due to its specific focus on regulating the provision of security services. In this context a PMSC can be understood as a commercial company selling security and support services, mostly internationally. The industry is heterogeneous and includes both reputable companies and ad hoc ventures of lesser quality and with less focus on operational ethics. Most companies rely heavily on former military personnel, but law enforcement personnel are also frequently hired. The companies sell services such as guarding (armed or unarmed), protection of persons and assets, specialised security training and risk mitigation, security audits and assessments, and anti-piracy services. Many supply logistics or support functions, such as sea, land or air transport, and some provide more specialised functions, such as demining, security sector reform (SSR) programmes, intelligence, disaster relief services, kidnap and ransom services, etc. ${ }^{6}$ It should be noted that when referring to its own contracting, the United Nations does not use the term 'military' and recently has expunged this word from security services. In UN parlance, then, the term private security company (PSC) is used. ${ }^{7}$ While the United Nations may wish to play down their military aspect, the more established term for companies such as Aegis, DynCorp, ArmorGroup and Global Risk Strategies (all frequent UN partners) is currently PMSC. In accordance with the terminology used by the Montreux Document, this paper will use the term private military and security companies (PMSCs).

In terms of conceptualising PMSCs, dominant actors within the industry have contributed to the debate and made efforts to brand or rebrand the industry in a more favourable light. This is done in order to accommodate customer concerns with the nature and legacy of PMSCs and 
remedy some of the controversy which has surrounded the industry. The mercenary association which has lingered around the industry is seen as a particular impediment to its positive contributions, and removing this association is crucial to changing negative perceptions among the public, policy-makers and contracting officers. The image of security contractors as trigger-happy and unaccountable cowboys has for the most part been incompatible with the security strategy of most humanitarian organisations and their public images, and has often been undesirable for many other clients such as government agencies. Consequently, labels and denotations have changed over the years in tandem with business aspirations and market demand. For example, the association of the US private security industry, the International Stability Operations Association, until late 2010 known as the International Peace Operations Association (IPOA), has been reconceptualised several times. ${ }^{8}$ The industry has thus shown that it is not only flexible in terms of what it offers, but also that its conceptual shaping is periodically remodelled to reflect the most attractive clients, their goals and the corresponding commercial ambitions of the industry in any given period.

\section{Filling a knowledge gap}

While the industry has certainly managed to gain entrance into what can be called a 'peace operations segment', there is not much written specifically on UN use of PMSCs. Nonetheless, most analysts and commentators acknowledge that several members of the UN family contract PMSCs on a more or less regular basis. ${ }^{9}$ Similarly, the practice of UN humanitarian organisations buying services from PMSCs is also well known among observers. ${ }^{10}$ However, little substantive or systematic information is available to outsiders on how and why the United Nations contracts PMSCs. ${ }^{11}$ Within the United Nations, detailed information has reportedly been gathered. ${ }^{12}$ However, UN agencies have released little to no information about contracting practices with PMSCs. While some organisations may be willing to share information on this topic 'for the right reasons', others do not authorise their staff to participate in or provide information to studies of UN use of PMSCs. Information on security arrangements is often both proprietary and confidential, and the sensitivity of the issue in UN circles has clearly limited the amount of information 
available. Several companies will acknowledge having worked for UNaffiliated clients, but mainly due to client confidentiality clauses in PMSC contracts this information is normally limited in detail and substance.

Accurate and comprehensive information has at times been hard to come by, and moving beyond anecdotal data has been difficult. When interviewed, UN representatives have generally not been overly willing to elaborate on policies and practices. In some cases, procedures to deal with PMSC contracting have been portrayed as somewhat more established and structured than was later found from other sources. To compensate, this paper relies upon a variety of sources, including UN documents, governmental reports and documents, academic research, journalistic material and some interviews. Nonetheless, an exhaustive mapping of UN use of PMSCs is not feasible and the information in this paper may not provide the complete picture on UN contracting. Rather, it is an attempt to shed some light on a common but little-documented practice. The study is largely limited to international PMSCs and does not treat contracting of local security companies in any detail; it does not address formal or informal deals with local armed factions, or moonlighting security outfits. ${ }^{13}$ This focus is chosen despite the fact that most sources report that the vast majority of UN security contracting is done with companies local to the operating environment. Local security contracting seems often to be preferred over international PMSC contracting due to beliefs that local guards will be more acceptable to the local population and constitute good sources of detailed security information. Also, there are aspirations to contribute to the local economy and train the local population. Nevertheless, local security contracting may bring up a set of different dilemmas, and thus not be the more suitable option. ${ }^{14}$ While not addressed in this paper, UN practices and policies concerning hiring local security actors clearly merit further study.

This paper focuses broadly on the 'UN system', with special emphasis on the Secretariat, programmes and funds, i.e. the service-providing organisational apparatus, largely excluding the member states and the political international decision-making forums. It should be stressed that despite ambitions to deliver as 'One UN', the United Nations cannot be thought of as a unitary actor due to its 'conglomerate' and decentralised nature. Different parts of the organisation at times may have conflicting interests and goals which lead them in different directions in terms of 
approaches and policies. Analysing 'UN attitudes' and 'UN practices' thus necessarily leads one into a multidimensional analysis of heterogeneous and diverse organisations. Nevertheless, the different parts of the UN system do not, of course, exist completely unrelated to each other. The Secretariat, the humanitarian organisations and the peacekeeping apparatus all need to relate to each other both formally and informally. In the field, the security environment is affected by actions and affiliations of fellow UN entities, and security solutions chosen by one entity may affect the security of another operating under the same UN flag. Thus this paper takes a broad focus when looking at some of the practices and policies coexisting under the UN umbrella. For reasons of simplification, however, references to 'the United Nations' will at times occur throughout the text.

Three operational contexts are studied in this paper: humanitarian operations, peacekeeping operations and political missions. The United Nations also contracts PMSC services in relation to natural disasters and in normal country work to promote development, but these two areas of operations are not specifically dealt with here. Arguably, not focusing on country offices may mean that a considerable amount of PMSC contracting that takes place under the UN umbrella is not covered. The issue of PMSC participation in UN country teams is comprehensive and multifaceted; it is beyond the scope of this paper and should be subject to further study. This paper also excludes from its scope the specialised agencies operating as autonomous organisations, such as the Bretton Woods institutions. These maintain their own security arrangements and do their own security procurement even if they are still often formally part of the UN security management system.

The paper sets out to address some empirical findings regarding the UN's use of PMSCs in the contexts of humanitarian and peacekeeping operations and political missions. It then proceeds to look at the UN's demand for PMSC services analysed from an institutional perspective, focusing on security and protection services, peacebuilding support services and mission support services. The main part of the study is concerned with the premises for PMSC deployment by different UN entities, and discusses some of the prevalent UN approaches to PMSC use from the perspectives of safety and security, humanitarian affairs, peacekeeping, procurement and human rights. Finally, the paper summarises key findings and presents a number of recommendations for future action. 


\section{THE UNITED NATIONS AND PMSCS: AN OVERVIEW}

Discussions of PMSC involvement in UN operations are susceptible to some common misunderstandings related to the type of services bought, the comprehensiveness of PMSC reliance and the role the companies play. Firstly, PMSCs do not supply the United Nations only with security services; frequently they supply other specialised services such as advice, training, ${ }^{15}$ demining, logistics, etc. Secondly, corporations do not stand to substitute UN missions any time soon, though in the past some have prepared proposals for rather extensive operations to remedy UN member state inaction. ${ }^{16}$ PMSCs are not used as front-line peacekeepers, and peacekeeping is therefore far from being taken over by private companies as some have feared and others have suggested. ${ }^{17}$ As Spearin has pointed out, it is also highly unlikely that most contemporary PMSCs would have the capacity to muster the adequate response to do so in a timely manner. PMSCs are most often composed of diverse personnel, not gathered to capitalise on their collective abilities in ways which would be the case with armed forces. ${ }^{18}$ Instead, companies work in concert with UN operations performing selected tasks that the organisation does not have the capacity or means to deliver. Thirdly, PMSC services are not always directly procured by a UN entity; they may also be seconded to an operation by a member state or provided by third parties. While there is little in UN documents or departmental policies to indicate that PMSCs actually do perform a range of second-rank tasks within UN operations, there are indications that the practice is already well established and new services may be added to the 
shopping list in the future. However, the scale of such practices still seems to be somewhat limited. But hostile operating environments may suggest an extended reliance on commercial security services, perhaps including services such as hostage negotiation, extraction and evacuation which currently are prohibited by the General Assembly from being contracted out. ${ }^{19}$ Services pertaining to the peacebuilding aspect of the UN agenda are also likely to grow, including SSR-related activities such as police and judicial reform as well as expanded training and capacity-building roles.

\section{Direct versus indirect UN use of PMSCs}

The United Nations directly procures PMSC services from its headquarters and in the field, and a variety of agencies, programmes, funds, departments and divisions within the UN family are regular PMSC customers, including the UN Children's Fund (UNICEF), World Food Programme (WFP) and UN Development Programme (UNDP). Direct contracting is apparently done from time to time in spite of the general rule that only the specialised agencies should procure directly. The remainder use one of the procurement organisations or the Department of Field Support.

PMSCs also frequently get involved in UN operations through member state contingencies. This is a particularly common practice as far as US contributions to the United Nations are concerned. In fact, since the US administrative structure does not allow for a federal police force to be seconded directly to international missions, the State Department (DoS) relies entirely on recruiting police personnel from private contractors. These companies vet and hire civilian police personnel from state, local and municipal law enforcement agencies and subsequently supply police services to international peacekeeping and other missions without consulting or informing the United Nations. Police-contributing countries merely undertake to provide the service and the number of agreed police officers without further specifications given to the United Nations.

Until April 2004 DynCorp International was the sole supplier of US civilian police to the DoS, meaning that every US police officer taking part in UN Civilian Police (UNCIVPOL) was in fact a DynCorp employee. Since then the contract has been split up between a few additional companies that maintain rosters of police personnel. ${ }^{20}$ Pacific Architects \& Engineers (PAE) is part of the effort, and according to its website currently contributes 
civilian police personnel to the UN missions in Haiti and Liberia. ${ }^{21}$ Similarly, in 2003 DynCorp won a major and potentially lucrative contract with the US DoS for 'Peacekeeping Support in Africa' where the company would be on call to perform 'any and all services required for Peacekeeping, Capacity Enhancement and Surveillance Efforts within the continent of Africa'. It was an 'indefinite quantity/indefinite delivery contract' with a maximum value of US\$100 million. ${ }^{22}$ The same company won the 2009 extension of African Peacekeeping, now called AFRICAP, ${ }^{23}$ a programme meant to support African countries in conducting peacekeeping operations. Both DynCorp and PAE have also been awarded contracts under the US peacekeeping capacity- and capability-building effort for African countries, ACOTA (Africa Contingency Operations Training and Assistance). Consequently, personnel and expertise provided as part of US contingents to peacekeeping initiatives, whether under the auspices of the United Nations or as part of bilateral support initiatives, are frequently drawn from PMSC contractors. As noted by Taulbee in 2002, 'international observers provided by the US to multinational operations [are] now more likely to come from private companies than from the regular military'. ${ }^{24}$

Developing countries may also rely on PMSCs in order to be able to take part in UN peacekeeping operations. For example, Paramount Group specialises in 'peacekeeping packages' tailored to help developing countries meet UN equipment, training and logistic requirements. According to the company's website, Paramount Group covers a niche in the market which US PMSCs often overlook: UN troop-contributing countries which are eager to mount a battalion for UN deployment, ${ }^{25}$ sometimes motivated by the UN reimbursement system.

Services can be required specifically by the organisation but paid for by member states. Both Aegis and Global Risk allegedly have been paid by member states to provide protection to senior UN officials in Iraq. ${ }^{26}$ PMSCs may also take part in UN operations through subcontracting procedures. A 'regular' contract for support or reconstruction functions may require security measures which may be subcontracted to a PMSC, which is consequently associated with the overall UN project, mission or organisation. Some member states also exercise their host-government responsibility to protect the United Nations by providing armed or unarmed security personnel from a private company instead of using public protection. Thus outsourcing policies of member states may lead PMSC 
personnel to take part in UN operations, resulting in an apparently significant indirect use of PMSCs by the organisation. However, since the topic of this paper is not member states' policies, but rather UN policies and practices, it is mainly concerned with direct UN procurement of PMSC services to compensate for internal incapacities. Nonetheless, more research on the role of PMSCs as part of member state contributions or contingencies would benefit overall knowledge about the commercialisation of contemporary peace operations.

\section{PMSCs in UN humanitarian operations}

In humanitarian operations, national and international PMSCs are being deployed for the protection of staff and premises, risk assessments and security training. In extreme situations this may imply provision of a proactive armed presence to prevent attacks and allow continued humanitarian presence. ${ }^{27}$ According to one study conducted almost ten years ago, the most common services provided to humanitarian organisations (both UN and non-UN) were risk analysis, security training of staff, crisis management advice (for instance regarding kidnapping), security assessments and the provision of guards (mostly unarmed) for the protection of assets, offices, residences and other premises. ${ }^{28}$ Since the establishment of the UN Department of Safety and Security in 2005, agencies in theory need to seek specific authority from the DSS in order to buy armed security from the private sector. ${ }^{29}$ However, it is doubtful whether these procedures are always adhered to. Based on interviews with a range of members of the humanitarian community, Stoddard et al. report a similar pattern in 2008, emphasising in particular the prevalence of security training, risk assessment and security management consulting as well as unarmed guarding services. According to the study, the majority of unarmed guarding services were bought from local providers. ${ }^{30}$ UN agencies are, however, reported to contract less for risk assessments and security management than the non-governmental organisations (NGOs) in the study, indicating that for the most part the DSS adequately covers these needs for UN entities. ${ }^{31}$ In the past there also seems to have been a practice of occasional hiring of security officers from PMSCs. The company Defence Systems Limited (DSL), for example, supplied security officers to UNICEF in Sudan and Somalia, as well as to the WFP in Angola. ${ }^{32}$ According to 
Stoddard et al., the services most frequently bought from PMSCs by UN agencies were physical security for facilities, followed by security training. UN agencies also reported the use of armed protection more frequently than other humanitarian organisations. ${ }^{33}$ A UK parliamentary committee reported in 2002 that while the UN civil security division (then UNSECOORD) restricted the use of PMSC services by UN humanitarian agencies, the UN High Commissioner for Refugees (UNHCR) very often demanded them. ${ }^{34}$ Statistical reports of UN contracting confirm some of these reports. In 2008 the UNHCR, for example, contracted ArmorGroup Kenya for 'office security services', while UNDP bought security services from Saladin Security in Afghanistan. ${ }^{35}$

The World Food Programme serves as an illustration of a UN agency that recurrently relies on a broad range of security services supplied by a private security company. According to Hart Security, the company supplies the WFP with extensive security assessments that cover all aspects of the agency's activities in a range of different countries. These services include 'political risk assessments, covering likely developments that will affect security in the country, through to a thorough analysis of threats to operations and personnel and compliance with established security protocols and legislation'. ${ }^{36}$ There is no mention of physical security services, which are a somewhat more controversial topic for the WFP, but convoy and warehouse security are services likely to be included, depending on threat assessments and other contextual factors.

\section{PMSCs in peacekeeping operations ${ }^{37}$}

The tasks performed by private actors in peacekeeping operations are normally restricted to support functions and some security functions rather than those of a military nature. ${ }^{38}$ The United Nations currently contracts PMSCs for services such as static security guarding, logistic support and demining and ordnance disposal during peacekeeping operations. ${ }^{39}$ The level of PMSC contracting appears to vary, depending on both the level of difficulty of the mission and the often corresponding difficulty of getting the needed personnel. Certain missions are likely to be less attractive due to location, or the level of insecurity associated with the mission, and thus more prone to personnel shortage. Examples of PMSCs supplying services in support of peace operations include DynCorp supplying helicopter 
transport and satellite network communications to the UN-sanctioned International Force in East Timor, ${ }^{40}$ while DSL provided both logistical and intelligence support for national contingencies participating in that mission. ${ }^{41}$ PAE provided general logistics in support of the UN Mission in Sierra Leone in 2000 and 2003 and various logistical services to the UN Mission in the Democratic Republic of the Congo (MONUC) in 2001. ${ }^{42}$

In many cases services seem to be procured in combination: logistic services are often combined with security, which in turn may imply information-gathering or intelligence-like services. This was the case in the Democratic Republic of the Congo (DRC), where ArmorGroup provided both security and logistics to MONUC. ${ }^{43}$ Although many contracts seem to involve more than one service type, few of the cases recorded in this study appear to have reached the level of comprehensiveness and integration into the UN peacekeeping operation as did the contract between DSL and the UN Protection Force (UNPROFOR) in Bosnia in $1992 .{ }^{44}$ In this case the UN Department of Peacekeeping Operations (DPKO) hired at least four PMSCs (among them DSL and DynCorp), or approximately 2,000 civilians, to mount the personnel necessary for the intended operation. ${ }^{45}$ DSL contributed 425 international staff from 24 nations. Among the tasks carried out were crime prevention and detection, close protection and border security duties. The contract lasted four years until NATO forces assumed primary responsibility from the United Nations in $1996 .{ }^{46}$ As the mission grew, so did DSL's responsibilities. It supplied armoured vehicles to cover hardware deficiencies of the peacekeepers from Asia and Africa. As these battalions lacked the expertise to maintain and operate the vehicles, UNPROFOR requested DSL to supply drivers and mechanics. DSL also had to take care of the fuelling and maintenance of the vehicles, the constructing of bases to house them and their coordination (done by DSL planners in Zagreb). ${ }^{47}$ While initially hired for a diversity of security purposes, DSL ended up performing security, support and expert tasks. According to DSL's former director of international affairs, General Sir David Ramsbotham, it was a case of employing fully qualified and experienced personnel to fill gaps created by the lack of regular UN civil and military personnel. ${ }^{48}$ DSL employees wore civilian-pattern UN uniforms with UN badges and identification papers, and were fully integrated into the UNPROFOR organisation. Where regular soldiers normally would serve for six months, DSL personnel would typically serve for the entire contracted period of four 
years, thus increasing their indispensability. DSL contractors were also given access to classified information. ${ }^{49}$

The role played by PAE in MONUC serves as a more recent illustration of how a PMSC has been deployed in a UN peace operation. In June 2004 Congolese students released a wave of violence in central and eastern parts of the DRC in protest at the UN mission's failure to prevent atrocities in Ituri province. The frustration of the Congolese civil war was directed towards UN-associated personnel and facilities. PAE was an integral part of the UN operation. It ran six airfields for the mission and its employees drove UN vehicles and were considered UN workers by locals - and hence were also subject to attacks. The violence in Kisangani included burning the UN headquarters in the city to the ground, UN staff housing was attacked and burned, and over 70 UN vehicles were stoned and set ablaze. As the UN military contingent withdrew, $300 \mathrm{UN}$ staff fled to the local airport where they demanded emergency evacuation from the city, fearing they would be killed by the rioting mobs. PAE workers prepared for and carried out the evacuation of the UN staff, while the PAE teams stayed behind to complete their contract. ${ }^{50}$ This example in particular illustrates a fundamental dependency on commercial companies for essential tasks in certain peacekeeping operations, and suggests that at times private contractors may face more risks than UN personnel.

\section{PMSCs in political missions}

The UN Department of Political Affairs leads a number of political missions in Africa, South and Central Asia and the Middle East. These missions, charged with diplomatic and peacebuilding tasks to prevent or resolve conflict, are carried out in concert with the UN development and humanitarian entities. Some of these missions are currently located in hostile operating environments, such as the UN Assistance Mission in Afghanistan (UNAMA) and the UN Assistance Mission in Iraq (UNAMI). They are thus likely to require security contracting, including risk assessments and planning but also physical protection. Political missions are responsible for carrying out specialised tasks which may be supplemented or replaced by PMSC staff and services. One example is voter registration and election planning in Afghanistan, the responsibility of the Joint Electoral Management Body Secretariat (JEMBS), a partnership between Afghan 
officials and UN advisers. In this process, one PMSC has been particularly involved. Global Strategies Group (formerly known as Global Risk Strategies) worked with the United Nations and the Asia Foundation in the preparations for several Afghan elections in 2002 and 2004, and had two employees killed in the lead-up to the 2004 presidential elections. The main task of the company was identifying and assessing potential voter registration sites and locations for JEMBS provincial offices. Global Strategies Group also supplied services in the areas of communications and coordination, operations and logistics, as well as training and security advice and assistance..$^{51}$ According to the Asia Foundation:

\footnotetext{
Because of Global's flexibility and ability to travel to insecure regions off limits to UN staff, Global supplements JEMBS staff by establishing inter-agency meetings, conducting meetings with Shuras (local-level committees of village elders with enormous influence in an area), distributing civic education materials, and conducting training. ${ }^{52}$
}

While in this case PMSC staff were used mainly due to their security (survival) skills, they were in fact hired to carry out tasks normally done by UN electoral advisers, and as evident in the above quote, the contractors in fact exercised political influence on behalf of their employer. To the local population, distinguishing PMSC personnel from UN personnel may thus have been a challenge. According to a BBC reporter, 'In effect, here in Zabul, these two contractors have become the United Nations. ${ }^{53}$

In sum, in part due to a lack of transparency in UN use of PMSCs, some common misunderstandings prevail related to the type of services the United Nations buys, the scope of contracting and how PMSCs end up in service of the United Nations. Different parts of the UN system do from time to time contract PMSCs directly for security, security consulting, support services, logistics and a range of other tasks, as well as indirectly through member state contributions. The above cases drawn from humanitarian, peacekeeping and political missions respectively illustrate that PMSC involvement in UN operations in the past has ranged from sporadic and complementary to comprehensive and mission essential. The next section investigates some of the reasons for the increasing UN demand for PMSC services. 


\section{THE UN DEMAND FOR PMSC SERVICES}

Since the 1990s the demand for UN delivery on the ground has increased massively. The formulation of a 'culture of protection' and the 'responsibility to protect' established that the international community had responsibilities that transcended sovereign borders. Accordingly, UN peace operations have evolved considerably in scope, from interpositioning and observation to peacemaking, and further to post-conflict reconstruction. ${ }^{54}$ During this period there was also a shift away from Western states as prominent troop providers, towards developing nations largely taking over this task. At the same time, the new operational environments have often been characterised by complex conflict structures and multiple emergencies. Not only do they tend to require more comprehensive operations, but they also represent the riskiest operational environments for international relief or peace operations personnel. Combined, these factors have put the United Nations under enormous stress in terms of human, financial and organisational capacities, and have consequently greatly contributed to the increased UN use of PMSCs.

The UN departments, agencies, boards, committees, offices, networks, programmes and funds make up a complex web in the structure of the organisation. Lack of flexibility in decision-making, combined with slow processing time, has given the United Nations a reputation for being a cumbersome bureaucracy. It has somewhat condescendingly been termed a 'headquarters organisation', an expression which relates to the divisions often apparent between field personnel and the Secretariat in New York. ${ }^{55}$ 
In addition, competing aims and political divisions - often resulting from different mandates, roles and responsibilities - appear to hamper the effectiveness of the Secretariat, and this may be the case in terms of devising a common UN approach to PMSCs. In peace operations, their multilateral nature implies a range of inherent weaknesses such as language and culture-related incompatibilities, insufficient or incoherent training, differences in doctrines, inadequate or incompatible equipment, differences in terms of incentives (e.g. political versus financial), etc. These weaknesses are to a certain degree natural consequences of the principles under which the United Nations works, e.g. the principle of 'geographic distribution', meaning a UN peacekeeping force should contain personnel from a variety of world regions to avoid missions representing only a small and hence biased sphere of countries. However, other weaknesses appear somewhat less predestined. This section explores the UN demand for PMSC services from an institutional perspective, focusing on safety and security, peacebuilding tasks and mission support.

\section{Security and protection services}

The bottom line of UN security arrangements is still the principle that the responsibility rests with the host government to provide security for personnel, premises, property and activities. In response to divisions between field personnel and the Secretariat in New York, however, a second principle related to the internal system was added: the security management system should be unified, but decentralised to the country level. ${ }^{56}$ The UN demand for external security services appears to stem from weaknesses in the application of both principles, which will be addressed in turn.

\section{Host-state security responsibility}

Under the 1994 Convention on the Safety of UN and Associated Personnel, signatory states are obliged to prevent attacks on UN peacekeeping staff, and in case of such attacks to investigate and prosecute accordingly. The 2005 Optional Protocol extends this responsibility to include all other UN operations, whether humanitarian, political or developmental. The first problem associated with this principle is that by 2008 less than half of UN 
member states were actually party to the convention (84 of 192 member states), ${ }^{57}$ and the optional protocol did not reach the required 22 signatories to enter into force until August 2010. The majority of the signatory countries are moreover highly unlikely to host a UN operation any time soon. The United Nations thus continues to entrust host states with its security, although in many cases it does so without basis in a formal agreement with the involved state.

Another impediment is that missions are frequently carried out in weak or disrupted states. Host governments in such states may simply not have the capacity to fulfil obligations to the United Nations, irrespective of being a signatory to the 1994 convention or its optional protocol. In some cases the host state might not even have a clear incentive to provide security for UN personnel. The 2008 report of the Independent Panel on Safety and Security of UN Personnel and Premises Worldwide (IPSS) acknowledges that occasionally the perceived UN role in a given country does not inspire mutual trust between the United Nations and the host government. In other cases host governments may hesitate or resist an elevation of the UN security phase, a system used to describe and grade the security conditions in a given country, due to fears that it will impede foreign investments or tourism in the country. ${ }^{58}$ Risk mitigation measures are thus often a product of negotiation with host governments instead of resulting from a realistic threat assessment. In accordance with these limitations, the IPSS recommends a more relaxed emphasis on host-country security, and that the United Nations should assume a more 'realistic understanding' of what can and cannot be expected from security provision by host states. ${ }^{59}$ Accordingly, the organisation seems to be in the process of shifting the focus of security provision from host countries to its own apparatus or external sources. Such an approach could contribute to sidelining traditional state security apparatuses to the advantage of nonstate international, or private, security actors and arrangements. The United Nations, however, appears less than willing to revoke hostgovernment responsibility completely and has initiated experiments with a separate host-government agreement in an attempt to improve security collaboration between the organisation and host governments. ${ }^{60}$ 


\section{The unified and decentralised internal security system}

After a series of attacks on UN personnel culminating in the attacks on the UN headquarters in the Canal Hotel in Baghdad, killing 22 staff and visitors, an assessment of the UN security system was carried out. ${ }^{61}$ The concluding report led directly to the adoption in December 2004 of Resolution 59/276, which by establishing the new Department of Safety and Security aimed to professionalise the security system of the organisation. ${ }^{62}$ Another review of the new security system was carried out in the aftermath of the December 2007 terrorist attack on the UN offices in Algiers, which left 17 UN personnel dead and 40 injured. This report concluded that the UN office had been vulnerable to attacks due to both organisational weaknesses and individual personnel failures. In particular, the panel identified a need to build an organisational culture that 'embraces security as a common and shared responsibility'. ${ }^{63}$ The panel reported improved cooperation among different components of the UN security management system, and that security decisions now were better documented than before. However, it also noted that only partial progress had been made in terms of actually unifying the security system. ${ }^{64}$ It concluded that the system needed improvement in fundamental issues such as accountability, leadership, internal management and oversight. Flaws pertinent to day-to-day workings of the security system itself were also uncovered. ${ }^{65}$ These systemic weaknesses are not exclusive to the new security system; in fact, despite enhanced focus on security, reform and increased spending on security measures, the DSS seems to suffer from a range of the same shortages that plagued its component parts in the past.

The establishment of the DSS in 2005 brought together the security management functions of the DPKO structure for civilian staff in peace operations, the Office of the UN Security Coordinator (UNSECOORD) and the diverse individual safety and security service units at offices away from headquarters. ${ }^{66}$ The department is organised under the Office of the UnderSecretary General for Safety and Security and has three main sections: the Division of Security and Safety Service, ${ }^{67}$ the Division of Regional Operations and the Field Support Service. ${ }^{68}$ Parallel and additional security management structures operate within the UN agencies, funds and programmes; although clearly interesting and relevant, these are beyond the scope of this paper. ${ }^{69}$ 
Field security

Unless specifically mandated or in extreme situations, the DPKO does not normally provide security for humanitarian programmes. Peacekeeping operations (PKOs) most often do not coincide with humanitarian efforts (humanitarians are normally the first to arrive and often stay on after a PKO is terminated). ${ }^{70}$ They are also frequently overstretched, and in general do not always represent the best way to provide security for humanitarians as they may increase their exposure to threats from warring parties by compromising claims to impartiality. In the absence of a PKO, humanitarians have often had the choice of suspending operations or buying security or access from either local factions or warlords, local commercial security establishments or international PMSCs. According to Martin Barber, former chief of policy development and advocacy at the UN Office for the Coordination of Humanitarian Affairs (OCHA), the UN humanitarian agencies have used all three types of security providers in the past in situations where the host state is unable to provide security or in countries where the government has lost control over parts of its territory. ${ }^{71}$

The intersection between civilian and military security remains a challenge to the new security management system. In the presence of a DPKO-led operation, the DPKO hires its own security officers to work according to DSS established standards. They will provide security only for civilian components of the mission under the leadership of a DSS chief security adviser. The chief security adviser is thus responsible for managing the security section of peacekeeping or special political missions. However, according to the UN Office of Internal Oversight Services, there is lack of clarity regarding policy and operational matters tied to the position and reporting lines of the chief security adviser. ${ }^{72}$

While the DSS and DPKO can muster a substantial number of security advisory personnel to protect civilian personnel, this arrangement apparently does not adequately incorporate agencies that work alongside peace operations, with the possible exception of integrated missions, i.e. a mission which hosts both a PKO and a country team comprising agencies, programmes and funds. ${ }^{73}$ In the past there have been claims that the new security management system has paid inadequate attention to the security 
of uniformed personnel not part of the military contingent in peace operations, such as military observers and civilian police. ${ }^{74}$

\section{UNSECOORD: Civilian means to civilian field security}

Until 2005 UNSECOORD (the Office of the UN Security Coordinator) had overall responsibility for responding to security threats faced by UN personnel. UNSECOORD was as such the main means to provide security for civilian staff. However, a lack of capacity, due to resources not being granted by member states, coupled with organisational inflexibility and understaffing meant UNSECOORD was only capable of offering a very limited contribution to field security. The security system it managed was headquarters based, and relied on liaison with appointed security officials and advisers in the field. The overall security for a duty station was, and still is, the responsibility of a designated field official, a position which is frequently taken on top of other obligations, such as being the resident coordinator, head of an operation or head of another UN organisation. The designated official is also head of security planning, although rarely well trained in this capacity. In fact the training has been described as resembling short 'briefings' more than real training. ${ }^{75}$ Security in duty stations is therefore not handled as a matter requiring expertise, but as an additional concern which can be handled by UN managers who can factor in security issues while focusing on the management of programmes.

The designated official organises a security management team, often consisting of the heads of the UN agencies, programmes and funds present at the duty station, which will assist and advise on the security plan. ${ }^{76}$ The only position meant for a professionally trained security official is the field security officer, and this position is often not made available to UN duty stations. The system has suffered from a constant shortage of professional security officers at duty stations and organisational inflexibility in reassigning officers at short notice. ${ }^{77}$ In 2000 it was reported that the process of recruiting a field security adviser could take up to a year, partly due to cost-sharing regulations ${ }^{78}$ and cumbersome human resources processes. Illustrating the shortage, in 2003 UNSECOORD declared 93 missions 'hazardous', while numbers from the year after testify that only 64 missions had a professional security adviser present. ${ }^{79}$ In difficult operating environments a large number of security officers may be required, 
sometimes up to 20 at each station (e.g. in Somalia, Afghanistan, Iraq, Angola and Sudan), which places an additional strain on sparse resources.

The situation seems to have improved since the establishment of the DSS: the availability of advisers has picked up and the recruiting time has been reduced. ${ }^{80}$ The shortage of professional security officers at duty stations nevertheless remains a problem. As of 2008, about one-third of the countries where the United Nations has a presence still had no professional security adviser present. While all duty stations now have a security adviser assigned, he/she may have regional responsibility and not be present at the station. In those cases, the security adviser is represented by the local security assistant, usually a former senior police or military officer, who primarily acts as liaison to the government forces of law and order. If situations arise that require additional expertise, voids are apparently frequently filled by relocating a security adviser from another duty station, at times creating a demand somewhere else. ${ }^{81}$ The availability of specialist security guidance often seems inadequate, which may drive agencies and organisations to acquire the necessary competency from the private market. In many cases, hiring PMSCs for consultancy, training and assessments may have been done to avoid placing urgent humanitarian operations at significant risk while waiting for additional internal officers to be recruited, trained and deployed. ${ }^{82}$ According to a consultant to the WFP, 'the only fast way to deploy security staff is through professional security companies'. ${ }^{83}$

A closely related concern and an important area of commitment of the new security management system is security training. While there has been increased attention to training both at headquarters and in the field, the effort is apparently still characterised as 'unstructured', and according to an audit in 2008, the unit in charge, the Training and Development Section, was not in a position to ascertain whether all security personnel had received adequate training according to standards. ${ }^{84}$ In general the UN security training programmes are considered 'inadequate for an organisation responsible for the security of so many people' ${ }^{85}$ On a more general basis, many of the tasks allotted to the field security officer, such as security training of staff, comprehensive threat and risk assessments (normally including some degree of intelligence gathering and analysis), monitoring and management of staff movements, are prone to be 
contracted out even in cases where there is a security officer present, due to the daunting workload of such officers.

Agencies, programmes and funds rely on the security arrangements of the DSS and those security components developed on their own. The DSS does not have a field capacity that can be called on for convoy protection or security in refugee camps, and considerable resources have consequently been invested into the development of agency-owned security modules tailored to the specific needs of their mandates. ${ }^{86}$ This is apparently partly by choice of the agencies, as offers by the DSS to provide such services in return for additional funds have repeatedly been turned down. Agencies have argued that they are better served by their own personnel, who intimately understand the mandate and operating methodology of the agency. ${ }^{87}$ In fact, some of the humanitarian agencies, funds and programmes operate very independently and do not deal that much with the rest of a mission, and their practices in terms of PMSC contracting or other security arrangements are thus not always clear. ${ }^{88}$ However, their security arrangements are dependent on voluntary contributions, as field security measures are not funded centrally from the regular budget, ${ }^{89}$ which may make expensive contracting difficult to sustain in the long run. Nevertheless, ArmorGroup officials testified to the company being responsible for the general security of at least one UN organisation in Baghdad in $2005 .^{90}$ More recent examples include the UNHCR contracting G4S Gurkha Services in 2008, and frequent contracting of IED Security, a Gurkha company hired several times from 2006 to 2008 for security and training services, mostly by one of the UN procurement agencies. Another example is the 2007 procurement of security services from Edinburgh International, a frequent supplier of mobile security services. ${ }^{91}$

Convoy protection seems to be a precarious capacity within the organisation and only carried out by peacekeepers. However, in the absence of a PKO, a range of situations in the past have called for PMSC convoy or related protection. LifeGuard (a South African company with close ties to Executive Outcomes) and DSL were both contracted to protect UN relief operations in Sierra Leone in 1998, one year prior to the establishment of the peacekeeping mission. Similarly, DSL was approached by the organisation in Somalia in 1992, the very year the peacekeeping mission (UNOSOM) was established, to deploy no fewer than 7,000 Nepalese Gurkhas to protect NGO relief convoys from threats posed by 
warlords. DSL, however, did not accept the contract. ${ }^{92}$ In some difficult missions, the UN peacekeeping forces seem overstretched and therefore unable to fulfil all of their duties. In such situations they are sometimes supplemented with private security resources. This seems to be the case in the highly complex UN mission in the DRC, where PAE is reported in the past to have handled security for UN infrastructure and personnel in Kinshasa. ${ }^{93}$

Although the humanitarian agencies do resort to PMSCs for civilian security services, most appear less than overly enthusiastic about this practice. A common concern relates to the paradigmatic difference in understanding of how to mitigate risk in military versus humanitarian thinking. In order to bridge this divide and acquire more humanitarian customers, several PMSCs now offer custom-made security solutions for humanitarians. Control Risks accordingly has set up its own team to manage NGO security, in which 'All of the team members come from an NGO background and understand the unique situations in which NGOs find themselves across the globe. ${ }^{94}$ Another commercial trend is to offer NGOs and humanitarians GPS tracking systems that would at least keep track of personnel or vehicles and speed up assistance or rescue in case of abductions or attacks. In the wake of the boom in commercial security demand in Iraq and the expected burst of the 'Baghdad bubble', the PMSC industry has both diversified and fine-tuned its security offers. From offering mainly security services, most companies now have expanded their repertoire to other types of services and customised old service offers to a variety of client needs, including those which better suit post-conflict scenarios and which accordingly may keep them in business even after military operations such as those in Afghanistan and Iraq are terminated.

\section{Headquarters, perimeter and personal security}

The issue of headquarters and perimeter security, and close protection of UN officials, has rested with the Safety and Security Services (SSS), now the Division of Headquarters Safety and Security Services (DHSSS). The new structure brings together the capacities of the former SSS, those of other offices away from headquarters and the security responsibility for the International Criminal Tribunals for the former Yugoslavia and Rwanda. ${ }^{95}$ In this particular division, the unification of the security management system 
has reportedly served to exacerbate old problems and intensify pre-existing tensions, much due to new reporting lines. ${ }^{96}$ Lacking flexibility, shortages of security specialists and insufficient training have continued to plague divisions such as DHSSS and hampered the accomplishment of a professional standard. It also seems that risk acknowledgements and security system improvements as a general rule have been implemented reactively, after major attacks have taken place or the situation has become precarious. Simultaneously, with UN headquarters increasingly seen as valuable symbolic targets for insurgents and terrorist groupings, the requirements of this unit have increased substantially in a relatively short period of time. The failure of the SSS to 'keep alertness to match the threat level' was unfortunately demonstrated by the bombing of the UN headquarters in Baghdad in 2003. ${ }^{97}$ After the attacks, Global Strategies Group reportedly supplied a range of security services to the United Nations in Iraq. Following these developments, there has been a marked increase in the number of senior officials given personal protection by the DHSSS Close Protection Coordination Unit, adding further strains on the organisation. ${ }^{98}$ Close protection or personal security details as well as perimeter security are services at the heart of the expertise of many PMSCs, and several have been known to cater to the United Nations. DSL, ArmorGroup and several 'Gurkha' companies have on a number of occasions covered services pertaining to the domain of SSS/DHSSS regarding protection of headquarters and premises, training, supply of guards, close protection, etc. ${ }^{99}$

PMSCs thus seem to have been called for in situations where there is a rapid deterioration in security levels, as substitutes for inadequate inhouse capacity. A perception of the United Nations aligned politically to the West has in particular contributed to a widening of the gap between the actual demand for security functions and the internal availability, often leaving little choice but to resort to private means in order to sustain presence. The 2009 suicide attack on the WFP office in Islamabad may be a case in point. The attack led WFP director Josette Sheeran to announce that the WFP would now bring in 'international experts' in an effort to redouble its staff protection, perhaps suggesting increased reliance on commercial actors. ${ }^{100}$ UN Under-Secretary-General for Safety and Security Gregory Starr later admitted to increased use of private security companies in Pakistan in response to a series of attacks, killings and kidnappings targeting UN 
personnel. ${ }^{101}$ Apparently, however, the Pakistani government made it clear it would not approve the use of foreign PMSCs.

In particularly dangerous operating environments PMSCs have been entrusted on a more frequent basis with security tasks normally within the domain of the DSS. For example, the political mission in Afghanistan (UNAMA) has relied on Global Risk Strategies for security training and assistance. Other companies known to have supplied these types of services include IDG Security, Hart Security, Strategic Security Solutions, DynCorp and Saladin. Strategic Security Solutions International, for example, was contracted by the UN Office for Project Services to perform security services at the UNOCA compound in Afghanistan in $2006 .{ }^{102}$

\section{Peacebuilding support services}

Extended scope and frequency of UN engagement have not only affected its demand for security and protection, but also exacerbated the need for a variety of expertise and support services. According to a study conducted by the US think-tank the Henry L. Stimson Center, finding expertise for peace operations was for many years a matter of hope more than planning and programming. Subsequently, as missions became more complex, the United Nations recruited a wider variety of specialists from outside the system. ${ }^{103}$ In terms of PMSC contracting, the more relevant expert services include intelligence, civilian police, demining and ordnance disposal as well as disarmament, demobilisation and reintegration (DDR) and SSR.

\section{Intelligence}

The combination of the UN's expanded scope for action with more insecure operating environments has made intelligence increasingly valuable in order to assess risks and guide action. Intelligence provision can be regarded an isolated activity, but in UN operations it more often forms an integrated and crucial part of planning for day-to-day activities in complex environments. The development of strategies for military operations, personnel protection and the planning of humanitarian operations all require informed risk assessments based on some level of intelligence or information on security environments. ${ }^{104}$ Especially when relying on the acceptance strategies most often used by humanitarians, or as an ordinary 
part of any risk mitigation, updated information may be crucial. It is also an important premise for many DDR programmes, since armed faction structures can be complicated and opaque to outsiders. Knowing 'who's who' in terms of combatants is thus crucial for successful planning and implementation of DDR programmes. In 2009 the DPKO and the Department of Field Support (DFS) identified 'information-gathering' (more specifically observation/surveillance, night operations capability and data management and analysis) as capacities in 'critical shortage'. ${ }^{105}$

There are thus few doubts about the utility of intelligence to the United Nations, but there are serious impediments to its acquisition. Governments currently share information with the United Nations on a 'need-to-know basis', i.e. when governments think that the United Nations needs to know. However, member states have traditionally been reluctant to empower the United Nations to gather and utilise intelligence due to concerns of interference in internal affairs, or that information gathered for UN operations can be exploited in other contexts. This has been reflected in a clear reluctance in the General Assembly to allow UN units to gather open-source information. On a practical basis, many states have been under the impression that the United Nations is inherently insecure and any intelligence in its possession would inevitably leak out to adversaries. ${ }^{106}$ Moreover, when such intelligence has been shared, its quality has frequently been questioned, adding to perceptions of poor intelligence in the UN context. ${ }^{107}$ There has also been scepticism within the civilian divisions of the organisation towards developing an intelligence capacity, mainly due to it often being seen as a predominantly military tool. ${ }^{108}$

For a few years the United Nations did have a very limited analytical capacity in the now-defunct Information \& Research Unit of the Situation Centre of the DPKO, but even then the information was not readily available to the UN community. The unit consisted of only four officers from the intelligence branches of the militaries of four of the five permanent members of the Security Council. ${ }^{109}$ However, suspicion from other states led the unit to be phased out. Similarly, a later attempt by the Secretary-General to create an in-house analysis unit to integrate the UN's various databases and reports was stalled by governments fearing it would evolve into a central intelligence agency. ${ }^{110}$ Thus, lacking both internal means to supply the organisational apparatus with adequate amounts of reliable information and the will of member states to remedy such 
conditions, the United Nations has largely relied on informal and ad hoc initiatives to acquire information. This has meant reliance on member states' occasional sharing of intelligence, some cooperation with NATO and also contracting for intelligence on specific issues and in specific situations.

In 2006, however, the DPKO adopted a policy of establishing joint mission analysis centres (JMACs) and joint operations centres in all peace operations. The units were meant to 'ensure that all peacekeeping missions have in place integrated operations monitoring, reporting and information analysis hubs at Mission headquarters to support the more effective integration of mission-wide situational awareness, security information and analysis for management decision-making ${ }^{111}$ While the main raison d'être of these structures is to serve mission integration and help improve decision-making and the country strategy, they also to some extent serve as a tool for the safety and security of UN personnel, as well as intelligence for operations. In fact, several JMACs have been perceived as prioritising the needs of the security or military components of missions. ${ }^{112}$ The PMSC industry for its part has gained a great deal of experience and capacity in intelligence gathering and analysis, especially in the aftermath of the 11 September attacks. The US authorities appear to have driven much of this demand. ${ }^{113}$ Intelligence services have thus become an integrated part of the service menus of most PMSCs, and the United Nations has also bought such services from the private security industry in the past. Sandline International provided tactical intelligence and helicopter transport to the UN organisations in Sierra Leone in 1998. The company also ferried UN reconnaissance parties in and out of areas inaccessible by road. ${ }^{114}$ In 2001 a Security Council committee monitoring sanctions violations in Angola hired Kroll Associates for nearly $\$ 100,000$ to trace the financial assets of rebel leader Jonas Savimbi, a measure which was met by scepticism by a range of member states. ${ }^{115}$ Similarly, the UN operation in East Timor (UNTAET) sought local intelligence-gathering services from two South African PMSCs, KZN Security and Empower Loss Control Services. ${ }^{116}$ In addition, it is likely that some degree of intelligence is part and parcel of any security contract in contexts such as Iraq, Pakistan, Sudan and Afghanistan. 


\section{Civilian police}

The salience of successful international police missions in establishing stability in the reconstruction of post-conflict societies has been increasingly acknowledged. Numbers of police personnel deployed in peace operations have increased accordingly. In September 2011 the United Nations had 14,310 police deployed in a total of 15 peacekeeping missions worldwide, more than a doubling of personnel since September 2005, when the number of missions was actually higher (17). ${ }^{117}$ Traditionally the main tasks of UN police have been limited to monitoring, observing and reporting, but these have been expanded to include reforming and restructuring local forces, training and advice, as well as in some cases assuming responsibility for direct law enforcement. Mandates often include several of these tasks. While in the majority of missions UN Civilian Police do not carry out executive policing, ${ }^{118}$ their tasks have generally evolved historically through what can be distinguished as five phases, each representing increasing scope and complexity. The first phase was limited to monitoring, while the second expanded mandates and activities to include responsibility for training components. The third phase represented an evolution of training to substantial reform and restructuring of the existing police structures, sometimes involving the creation of new institutions. Phase four extended UNCIVPOL to include specialised constabulary units, and the last phase extended mandates to provide them with executive authority - essentially the duty to bear arms and make arrests. ${ }^{119}$

As part of this evolution, the United Nations has introduced formed police units (FPUs), which are cohesive units composed entirely of elements from one contingent. These units represent an effort to close the security gap between the deployment of military personnel and civilian police. They are also meant to allow local police to be trained in accordance with democratic norms and standards, and as such avoid paramilitarisation of the police in often violent post-conflict environments. FPUs, where available, consist of about 125 armed officers per unit, normally deployed for crowd control or other response capacities to 'prevent security situations from escalating' in high-risk operating environments. Other envisioned tasks of FPUs include protection of UN personnel and facilities, security support to national law enforcement agencies and capacity 
building. ${ }^{120}$ FPUs are, however, only available in a very limited number of PKO missions and do not support the overall safety management system or the community as a whole. Further improvements to the UNCIVPOL capacity include the establishment of a rapid response unit, the Standing Police Capacity, which has been operational since 2007. The unit is formed by a group of senior police officers and managers tasked with organising the start-up of police components as well as providing expertise to existing missions. ${ }^{121}$

While there apparently has been increased attention to police capacities in peace operations, in terms of both training and executive functions, there are still weaknesses in the approach which limit effectiveness and have created an incentive for the United Nations to contract PMSCs for certain police services. ${ }^{122}$ One long-standing issue concerns unsatisfactory recruitment and training, as member state contributions often do not match demand in terms of quality or quantity. Most member states do not have an excess of qualified police that they can make available to a UN mission without impairing important tasks at home. In cases where the United Nations is offered civilian police officers, they often fail to live up to the requirements. In some cases personnel lack democratic training or tradition. ${ }^{123}$ Other impediments to providing better police have included corruption and the lack of a common set of standards and practices or a common doctrine for training. Slow deployment, insufficient donor coordination and cooperation, and lacking or incapable local judicial and penal institutions to follow up on police work have also impaired CIVPOL police contributions. Regarding the FPUs, the situation is even worse as such units 'simply do not exist in the requisite numbers or areas of specialization'. ${ }^{124}$ Apparently the same concerns apply to specialised police such as investigators, strategic planners and organisational reform experts and trainers. ${ }^{125}$

In response to poor contributions from member states, both police officers and training packages have been procured from PMSCs in the past. However, indirect contracting of police appears the more common practice. With regard to the US contributions especially, DynCorp supplies the UN Mission in Sudan (UNMIS) with a US contingent of up to 15 law enforcement, judicial and corrections advisers. These take part in training, equipping and mentoring the Sudanese police force. ${ }^{126}$ The United Nations has on occasions also directly hired PMSCs to supply missions with qualified 
police officers, for both direct deployment and training purposes. In 2010 UNMIS solicited so-called 'expressions of interest' from companies that can provide 'collaborative mediation skills for resolving internal disputes and peace building trainings for UNMIS staff', reflecting a shortage of in-house expertise available for this particular mission. ${ }^{127}$ While the United Nations does have a decent competency on training programmes, the location of particular missions might influence the availability of member state contingents.

PMSCs recruit a considerable number of former law enforcement personnel, and police and justice services thus have long formed part of their core service menus. DynCorp has, as mentioned, served within UN missions in the past, and DSL also supplied police training in Somalia in the early 1990s. More recently companies have been used to perform duties which conform to those normally carried out by national police in both Afghanistan and Iraq, partially reflecting the evolution in CIVPOL tasks described above. In Afghanistan, an Afghan subsidiary of the London-based company IDG Security reportedly was awarded a contract to provide 169 Gurkhas, allegedly to complement the services provided by the Afghan police. ${ }^{128}$ Similarly, Aegis was contracted by the UN Office for Project Services to provide public security during the 2005 Iraqi constitutional referendum and general elections. ${ }^{129}$ While it is implausible that Aegis personnel undertook the exact duties of local police, it nevertheless echoes a wider trend where the boundaries between civil guards and police forces are increasingly blurred. Such practices may influence morale of local police forces and thus impact on ongoing SSR and related peacebuilding processes.

\section{Mine action and ordnance disposal}

Effective demining is a particularly technologically demanding activity and at the same time a vital part of a peacebuilding effort. However, UN contracting for demining and ordnance disposal is the rule, not the exception, since the humanitarian UN bodies involved in mine action do not carry out mine clearance themselves but rely on peacekeeping troops, national civilian agencies, NGOs or commercial actors for these tasks. ${ }^{130}$ The UN Mine Action Service (UNMAS) thus serves only as a focal point for the 
coordination of the UN effort to eliminate landmines and explosive remnants of war.

Mainly due to the technical requirements of effective mine removal, several PMSCs have made their way into the demining market. PMSC personnel provide both mine clearance services and training for indigenous deminers. ${ }^{131}$ UNOPS confirms that demining constitutes a large share of its procurement activity, although the companies are not all PMSCs. ${ }^{132}$ ArmorGroup/G4S has gained a particularly important standing within this market segment and is also one of the implementing partners of UNMAS, along with well-known PMSCs such as EOD Technology and Olive Group. In 2006 the company won a $\$ 7$ million contract to remove unexploded landmines in Sudan, employing 200 staff. A year later it was contracted for IED (improvised explosive device) removal by the UN Mission in Nepal. ${ }^{133}$ ArmorGroup/DSL ${ }^{134}$ has carried out extensive UN clearance and training work in Bosnia and Mozambique, where DSL ran a UN course for four years, training managers and quality controllers of demining programmes. ${ }^{135}$ The same company performed clearance work under the UN Interim Administration for Kosovo and the Mine Action Coordination Centre. ArmorGroup has also been responsible for the demining of the buffer zone in Cyprus. ${ }^{136}$

\section{$D D R$ and $S S R$}

Security sector reform is a vital part of UN post-conflict peacebuilding. The United Nations has an SSR unit as part of the Office of Rule of Law and Security Institutions, which currently provides strategic support and advice to more than ten peacekeeping and special political missions. ${ }^{137}$ DDR programmes are often essential in the development of (cost-)efficient, accountable and well-trained security forces and a well-functioning state. The DPKO and DFS nonetheless experience great difficulties in acquiring civilian specialists, including police trainers, organisational reform and SSR experts and individuals with capacities in judicial and prison management. These skill sets were described as in 'critical shortage' in 2009. ${ }^{138}$ Differences in standards across member states may also constitute hindrances to the contribution of (for example) judicial expertise and SSR specialists overall. 
While PMSC involvement in UN SSR efforts so far seems to have been limited to certain training programmes, there are modest signs that the industry has performed services which pertain to related areas of the reconstruction process. The DSL contract in Mozambique apparently included elements of DDR, as the company was tasked with rehabilitating sugar plantations, which involved deliberate deployment of militia and their subsequent disarmament by DSL staff. ${ }^{139}$ Furthermore, Global Strategies Group's work identifying and assessing potential voter registration sites for several Afghan elections included training and educational tasks involving skills such as helicopter safety, loading of casualties, driving, etc. ${ }^{140}$ Moreover, many PMSC contracts are extensive and include elements of several service categories, and are flexible to the point where new services can be added if the need arises.

Offering SSR-related services appears to be a strong recent trend among PMSCs, and some now seem to downplay their protective services and instead highlight their 'peacebuilding' capacities. ArmorGroup traditionally listed protective security, security training and demining as its three main service areas. By 2005, however, the focus had shifted to postconflict reconstruction services and SSR, including DDR and police training programmes. ${ }^{141} \mathrm{MPRI}$, widely known for its military training capabilities, by 2005 also supplied 'Democracy Transition Assistance Programs' and 'peacekeeping and humanitarian aid'. ${ }^{142}$ As of 2010 the company has further expanded its SSR-related repertoire and now offers services within 'human rights training', 'rule of law and justice sector reform', 'organisational and institutional capacity building', 'military to civil transition assistance', 'natural resource management', etc. This serves as an illustration of the fact that UN peacebuilding tasks are increasingly viewed by PMSCs as an important market.

\section{Mission support services}

Effective support has always been critical to mission success, and as the size and scope of missions expand so must mission support. However, the shortage of logistic contributions was already a problem to the DPKO in the early 1990s. ${ }^{143}$ The dramatic augmentation in PKO deployment during that decade and its coincidence with aspirations for unprecedented levels of mission complexity have served to put further strains on the organisation's 
ability to muster the support services demanded by any given mission. ${ }^{144}$ Until the creation of the Department of Field Support in 2007, the UN logistic systems relied on member states being self-sufficient at unit level for a given period, normally between 60 and 120 days, awaiting the UN Field Service Unit organising support. ${ }^{145}$ Such a system is problematic given that the bulk of personnel in UN peace operations tend to be drawn from developing countries. Capacities for managing heavy airlift services, complicated logistic and communication systems, and maintenance of helicopters and planes are resource demanding, and poorly equipped and trained contingents are unlikely to have such skills. In line with the recommendations made by the Panel of UN Peace Operations in the Brahimi Report, there have been improvements to the pre-deployment arrangements for equipment. ${ }^{146}$ The upgrading of the UN logistics base in Brindisi, Italy, resulted in the base being able to support the rapid deployment of a headquarters for one traditional peacekeeping mission by $2002 .{ }^{147}$ In terms of rapid deployment, the cumbersome reimbursement system long required contingents to count and report all equipment to be used in an operation in order for calculations of reimbursements to be made. This system was thus an effective guarantee against rapid deployment of units to conflict emergencies, and may also have been a factor contributing to needs for external logistic support. ${ }^{148}$

Mission support also includes technical services. The UN Field Service Unit was created in 1949 to provide support functions such as land transport, radio communications maintenance, mechanics, security of premises and mission personnel, etc. to peace operations. ${ }^{149}$ However, from 1993 and for many years, the unit was seriously under-prioritised and subjected to a hiring freeze which prevented the rejuvenation of staff and the acquisition of up-to-date technological and logistic skills. ${ }^{150}$ The Brahimi Panel recorded in 2000 that the technical knowledge of the unit appeared outdated and its composition no longer matched the needs of the newer generation of peacekeeping. ${ }^{151}$ Consequently, by 2000 the obsolete and inadequate skills of the unit had led the DPKO to base itself mainly on services other than those of the Field Service Unit; eventually the unit's 460 personnel constituted just 13 per cent of the international civilian staff employed in UN peacekeeping. ${ }^{152}$ Until the restructuring of the DPKO and the inauguration of the Department of Field Support in 2007, the Field Service Unit retained its functions, at least on paper. 
Following the restructuring of the DPKO, the Department of Field Support was established, and within it the Logistics Support Division (LSD). LSD manages three categories of functions: operation support services (logistics, planning and programme support), specialist support services (technical logistical services, engineering, medical support, etc.) and transport and movement services (e.g. overseeing the operations of the UN logistics base in Brindisi). ${ }^{153}$ Recently the DPKO and DFS have elaborated and gained member state endorsement for a new global strategy for field support. The new approach entails the establishment of regional service centres which would make missions more resource efficient, eliminate redundancy and improve effectiveness and efficiency of the support apparatus. One such regional centre is planned for Entebbe, Uganda, while Brindisi is planned to be upgraded to a global service centre. ${ }^{154}$ The Brindisi base already has its own procurement section which handles the purchase of goods and services for the base - among the services listed as commonly procured are training, security, maintenance and technical services.

Despite valuable efforts to improve UN logistics and support capacities, mission complexity and infrastructure obstacles often place great demands on the support apparatuses. The need for logistics and support functions is likely to grow exponentially as operational activity increases and becomes more intricate. In 2009 the DPKO and DFS jointly identified enablers, engineers, logistics and transportation units among the critical shortages facing the departments. In an environment where the leading militaries outsource any non-core function and retain only warfighting capabilities, the prospects for member states to contribute nonprivate support capacities further decrease. Accordingly, logistics were also bought in many missions where developed countries were the main personnel contributors. In the case of the Australia-led mission in East Timor (UNTAET), DynCorp is reported to have supplied the United Nations with logistics, transport and communications. ${ }^{155}$ In the case of the UN Stabilization Mission in Haiti, International Charter Incorporated of Oregon has been engaged at various times to ferry UN personnel, troops and humanitarian supplies into and within the country to support the peacekeeping operations. ${ }^{156}$ In Angola DSL provided logistic support to the UN Angola Verification Missions in the past, ${ }^{157}$ and both PAE and ArmorGroup supplied MONUC with logistic services. ${ }^{158}$ 
Summing up, the United Nations has faced higher and more frequent risks to its personnel and assets in the operational environments where it maintains a presence. Host states have in response not been able or willing to provide the necessary security, and the internal security apparatus has not been able to absorb the resulting demand for increased security measures. The reformed and unified security system in part suffers from some of the same weaknesses that plagued its component parts before the unification in 2005, and resulting security gaps have at times been filled with PMSC capacities, while others have been left open. Some of the functions that PMSCs have performed in peace operations appear to result from lack of either political will of member states to empower the organisation (intelligence) or resources to supply the necessary amount and required quality of personnel and services (civilian police). Other tasks have traditionally been performed by state actors or NGOs, but are now also outsourced to PMSCs (mine action and SSR-related tasks). Greater operational activity and scope have led to additional demands for mission support services. However, as states themselves have often outsourced these services to the private sector, the United Nations has increasingly had to resort to the private market. Despite the fact that the United Nations uses PMSCs for a wide range of tasks and as part of peace operations, political missions, ordinary country work, humanitarian assistance and development efforts, these operational fields and the associated agencies represent different operational perspectives which do not always overlap in their principled or political approach to PMSCs. 


\section{UN POLICIES ON THE USE OF PMSCS}

As mentioned, the United Nations can hardly be described as a unitary actor, but more as a collective of different types of organisations guided by a common Charter and operating under a common flag. There is widespread UN use PMSCs, but no coherent or consistent policy approach managing the system's practice in this area. Rather, different political perspectives and practices abound throughout the organisation, and in part there is a coexistence of separate and sometimes contradictory approaches, reflecting the organisational deficiencies of the UN system. This section reviews the various policy approaches from different perspectives which together make up the multifaceted UN approach to PMSCs. ${ }^{159}$ Complicating the analysis is the fact that, apart from within the UN Working Group on the Use of Mercenaries as a Means of Violating Human Rights and Impeding the Exercise of Rights of Peoples to SelfDetermination, the issue of PMSC contracting has so far very rarely been dealt with in an open manner within the organisation.

\section{Safety and security perspectives}

Exploring the various perspectives on UN use of PMSCs, the safety and security of UN civilian staff, including humanitarians, serve as a useful point of departure. However, the DSS, the department responsible for the safety and security of UN civilian staff, makes very little information publicly available on its practices or policies in general. According to internal 
sources, this is due to a lack of clear policies and procedures. ${ }^{160}$ Finding coherent and consistent information on a DSS approach to PMSC contracting is thus unrealistic and guidelines for security contracting appear largely non-existent. Limited preconditions and procedures for PMSC contracting for security services can be found in an annex to the UN Field Security Handbook. These are applicable to situations where the UN's first basic strategy of host-state reliance is deemed inapt or insufficient, i.e. the many cases where the host government is not able to provide the necessary security arrangements for UN staff. The handbook states that 'under such rare and exceptional circumstance, the organisations of the United Nations system may protect their offices, premises and personnel by employing security service companies providing armed guards'. ${ }^{161}$ The annex was apparently originally intended to be used for offices, but morphed into accommodation and housing as well. Eventually agencies apparently used the annex to justify all types of security contracting. ${ }^{162}$

The handbook does not, however, provide much regulation on how guards should operate. A contract template to be used by UN agencies states that contractors shall comply with laws, ordinances, rules, regulations and the terms of the contract. No mention is made of rules for the use of force or other operating standards, what services can be procured or what limits should be placed on their operation. The document on the other hand appears attentive to the issue of liability, and states that companies contracted should be 'pursuant to local law to provide the services and should also be fully insured and licensed, so that they can effectively indemnify the organisation from claims'. Furthermore, the contract is meant to ensure that the contractor and not the UN agency is liable for 'actions, omissions, negligence or misconduct' committed by any of the contractor's employees or personnel. ${ }^{163}$

A section is included in the contract sample which specifies required uniforms and identification of guards, but the handbook provides very little guidance on selection criteria for private security providers. Vetting requirements to ensure that contractors have adequate training and lack criminal records or affiliation with fighting factions are absent. As pointed out by a representative of a major British private security provider, contrary to what some customers might think, PMSC security services have not been entirely commoditised, ${ }^{164}$ meaning that a certain price will not always assure that you get the professionalism or service quality one would expect. 
This necessitates qualitative standards to be specified in contracts. The Field Security Handbook has apparently been under review for a couple of years, but events and developments have delayed the process. The upcoming version will reportedly include more definite and concise procedures for PMSC contracting, including use-of-force guidelines. ${ }^{165}$ When exactly the new version will be published is unclear.

Similarly, the handbook contains sparse information on procurement procedures, such as whether it should be done directly by each agency, handled by one of the UN procurement agencies or run by the DSS. The document does state that security contracting requires the approval of the Under-Secretary-General for Safety and Security through requests forwarded to the designated official of each mission. While this policy is not new, there are indications that the procedure has not always been followed. Under-Secretary-General for Safety and Security Gregory B. Starr, who has held the position since May 2009, has been known to embrace the deployment of PMSCs in his past posts as director of the Diplomatic Security Service and principal deputy assistant secretary of the Bureau of Diplomatic Security, US Department of State. In this capacity Starr was responsible for all international and domestic security programmes for the DoS, which involved extensive outsourcing of diplomatic security to PMSCs - e.g. under Worldwide Personal Protective Services, which outsources a range of protective tasks such as 'armed protective services details' and 'counter-assault teams' to companies like DynCorp, Blackwater and Triple Canopy. ${ }^{166}$ While the principle remains that the United Nations should primarily rely on host-state security measures, the employment of a senior decision-maker with a high degree of familiarity with and apparent preference for outsourcing security services may be likely to influence security policy strategies in the UN Secretariat in that same direction, and/or encourage practices which lead to increased UN PMSC contracting. ${ }^{167}$ One indication that PMSCs may increasingly be included in DSS security strategies can be found in the 2009 report of the SecretaryGeneral on the situation in Afghanistan. The report states that following frequent attacks on UN personnel and facilities throughout 2009, all UNAMA offices now implement special security measures, including 'introduction of international armed security guards'. ${ }^{168}$ The plan also includes a range of other security tasks such as reviewing emergency plans, 
training and increased fortification of compounds - all common PMSC services.

Importantly, there is a recent initiative to remedy the poor regulatory situation of PMSC security contracting within the United Nations. A DSS working group including representatives from the DPKO/DFS and UNDP has been working on a proposal for the Secretary-General's Policy Committee suggesting a more coherent policy on contracting with private security companies. This policy apparently addresses a range of the problems pointed out in this paper and which plague the current 'hands-off' approach. ${ }^{169}$ It is hoped that such a policy would lead to guidelines and specifications for private security procurement to be devised by the DSS in cooperation with legal and procurement experts. The DPKO/DSS proposal will likely be controversial with some UN agencies and organisations, but could at least kick off a much-needed internal debate on UN practices concerning hiring PMSCs for security tasks. Such a debate may result in a policy which would have a bearing on the other approaches coexisting within the organisation.

\section{Humanitarian perspectives}

While the security of civilian personnel is formally the responsibility of the DSS, the humanitarian agencies most often also have separate arrangements for security. Some UN agencies rely primarily on their own inhouse capacity for the security of their staff and operations. At the same time they contribute to the DSS security function through a cost-sharing system (altogether 45 per cent of total DSS expenditure) calculated on a per capita staffing basis. This means that the largest UN humanitarian agencies will contribute significantly to the centralised UN security system while relying mostly on their own internal security arrangements; this has reportedly caused some tensions between the DSS and the UN humanitarian agencies. ${ }^{170}$ Large UN agencies acting independently of UN Secretariat security arrangements may have diverging approaches and practices towards commercial security contracting, and policies drafted centrally in the future may thus not necessarily be fully reflected in practices in the field. Also, both within the organisational apparatus and among many donors there is a perception that the security of agencies is a particular prerogative limited to each agency and not a matter for others to 
interfere with. ${ }^{171}$ Nevertheless, security practices and policies across the UN system are discussed through the Inter-Agency Security Management Network (IASMN); while this may have a certain coordinating and cooperative effect, the IASMN does not have decision-making power per se. It has also been criticised for being ineffective, and more precisely for taking too long to review and promulgate policies, and for these not reflecting adequately the needs of all members of the network. ${ }^{172}$ The IASMN may thus be an inadequate instrument to establish a blueprint for policy or practices in terms of commercial security among the agencies.

Although some PMSCs advertise security services specifically tailored to fit humanitarian needs, many humanitarians tend to have doubts about the compatibility of the often somewhat militaristic security approach favoured by PMSCs and the strategies implied in their own approach, often referred to as the 'the security triangle'. ${ }^{173}$ The preferred strategy, which in many operating environments has become unsustainable, is relying upon acceptance. ${ }^{174}$ This means that local actors and the population accept the humanitarian presence and actions, thus preventing them from being targeted ('softening the threat'). If this does not shield humanitarians from being seen as targets, protection is needed ('hardening the target to reduce impact'). Protection normally means securing premises, people and assets by different preventive strategies. Deterrence, the third and last resort, entails countering the situation ('posing a counter-threat') by threats of retaliation, the use of guards, military protection, etc. ${ }^{175}$ PMSCs are normally considered more relevant tools to humanitarians in situations when protection and deterrence strategies are used, but could also be used for consultation, training or intelligence purposes with regard to mixed approaches.

Apparently, there are varying attitudes to using PMSCs in UN humanitarian circles. Many humanitarians appear to be sceptical towards PMSCs in general due to the fact that they might be inclined to convey militarised perceptions, perhaps at odds with paradigms adhered to by the humanitarian clientele. There are consequently concerns that their use may contribute to a blurring of the distinction between civilian and military actors in conflict and post-conflict environments, especially if operating armed, as well as to confusion of UN and private personnel. 


\section{General guidelines}

The role of the UN Office for Coordination of Humanitarian Affairs is to mobilise and coordinate international and national parties in humanitarian operations. This formidable task includes coordination of civil and military efforts, enabling cooperation or at least establishing grounds for reasonable coexistence. ${ }^{176}$ As part of this work, the Civil-Military Coordination Section develops guidelines, training programmes and other field-related support activities. In the case of civil-military interaction the OCHA subscribes to the guidelines accorded to by the member organisations of the Inter-Agency Standing Committee (IASC). ${ }^{177}$ Perhaps reflecting different organisational policies and practices, guidelines specifically targeting PMSC deployment remain absent. The policy document most often referred to on this matter is a 2001 discussion paper on the use of military or armed escorts for humanitarian convoys. The paper was a result of an IASC initiative, but since the IASC does not have the authority to draft security policy, it was met with resistance within the civil security division, UNSECOORD. Eventually, UNSECOORD agreed to the drafting of a guidance paper with non-binding status. The document recognises that within the UN framework different organisations have had different policies on the use of armed escorts, but in general have reflected willingness to use armed convoy escorts in 'exceptional circumstances' ${ }^{178}$ The non-binding status of the guidelines implies that member organisations of the IASC, including UN agencies, may decide to resort to other practices than those suggested in the document when deemed appropriate, preferable or necessary.

The guidelines state that as a general rule armed guards should not be used to protect humanitarian convoys, with no distinction made between national armed forces, international peacekeeping forces or private companies. The general exception to the rule concerns cases of last resort in security vacuums. There are four criteria which add up to qualify as such a situation: clear unwillingness or inability of the relevant state to secure the environment; that lack of humanitarian assistance would cause 'unacceptable human suffering'; that armed guards could be used in such a way that it would secure humanitarian workers without compromising security for others; and finally that their use would not harm the long-term capacity of the organisation or the implementation of its mandate. ${ }^{179}$ According to the document, the determination of whether or not a 
situation meets the criteria is normally made by the designated official in the field, who in effect authorises the use of armed guards. ${ }^{180}$ While the first two requirements relate to an exceptional need for armed services, a situation which is likely to be recurrent in many operations, the latter two relate to the consequences and effects of armed guards and may thus be harder to assess at the outset. These two criteria in particular leave room for individual judgement to be decisive when assessing whether or not armed enforcements are to be used. This point seems reinforced by the DPKO, which holds that in case of requests for military security support covered by the IASC guidelines, 'in many cases the Designated Official would have a standard policy in this regard, and the relevant stakeholders can act according to this guidance in consultation with the most recent local UN Security Officials' ${ }^{181}$ DSS officials nevertheless restate that there is a lack of standard policies and designated officials may neither formally authorise the use of armed guards nor devise new standard policies. ${ }^{182}$ This gives the impression that in the absence of clear policies, practices emerge depending on assessments and discussions in the field, and on each agency's preferred approach. There appears to be frequent discord between the DSS on the one hand and the security professionals of agencies, programmes and funds on the other. This dissent can be traced back to the status of the guidelines, which appear to be interpreted differently. While the DSS holds that they form guidance only, other agents may interpret them as permissive policy, sometimes extending beyond humanitarian convoy protection.

Before the drafting of the IASC guidelines, a different criterion was deployed. According to a former OCHA official, by 1999 UN humanitarian agencies already had a history of resorting to both commercial companies and local armed groups for security or protection in situations where the host state was unable to provide security. The criterion for such use was local government approval, although it is admitted that this was frequently not adhered to. ${ }^{183}$

The IASC guidelines are more restrictive than both those referred to above and those found in the 2006 Field Security Handbook (although the handbook refers to static security as opposed to mobile convoy protection). The handbook only makes reference to the need for such services, i.e. inadequate host-state security in dangerous operating environments, and does not address the fact that potential negative consequences for 
populations or mandates should be part of the standard assessment when deciding whether to use armed guards. ${ }^{184}$ The practice and principle of securing host-state approval of such deployment may have been toned down in the handbook due to the increasing number of UN operations located in internal conflicts and weak states. In places like Afghanistan the use of static armed guards supplied by PMSCs has become standard procedure for most international actors and organisations present, due to the United Nations having costly experience with relying on host-state security in the past.

Other guidelines regarding civil-military interaction do exist, but they either explicitly or implicitly avoid the topic of PMSCs as actors that should be taken into account. ${ }^{185}$ Commonly, no particular justification is given for a restricted focus on state assets or capacities. While there might be good reasons to separate public from private actors or assets, there is also a need for guidelines on interaction with private security or military actors, as they too could alter perceptions of humanitarian neutrality and impartiality. The unclear civil-military division is an increasing concern for humanitarians operating in environments where military operations are ongoing. The IASC guidelines reflect the concern for compromised impartiality as a result of military escorts, but also recognise that using armed guards can be the lesser evil. If humanitarian organisations refuse to use armed guards for their convoys and thus are forced to abandon operations, it may advance the tendency for militaries to carry out humanitarian tasks directly as part of changed military doctrines. Such intermeshing of spaces and roles is likely to compromise further the impartiality of humanitarians and thus endanger their operations in the longer run. ${ }^{186}$

In sum, there are no specific UN general guidelines for humanitarians on the use of PMSCs or their interaction with these companies for purposes other than convoy protection. ${ }^{187}$ The guidance is limited to providing criteria for when to use private armed guards and fails to address important questions regarding how to use them, how to select them and what specific demands to place on such contractors. Guidelines are highly relevant in terms of judging whether the last two criteria for when to use armed guards are met, making sure that the negative effects on the local population or local conflict environment are as small as possible. The authority of the convoy guidelines can also be questioned, as they were not readily endorsed by the DSS and have caused dissension between the DSS 
and field security professionals. Accordingly, establishing clear guidelines entails clarification of accountability and decision-making structures. At the very least, having guidelines or checklists for humanitarians to consider when deciding whether to contract for security could potentially have a useful coordinating effect when developing mission-specific civil-military interaction guidelines, which exist for a number of missions.

\section{Mission-specific guidelines}

In the case of the UN Assistance Mission in Iraq, the acceptance model has been largely abandoned and a 'low-profile approach' recommended. The mission-specific civil-military guidelines nevertheless restate that armed protection should be considered an extreme precautionary measure to be taken only in exceptional circumstances and on a case-by-case basis. ${ }^{188}$ The 2004 guidelines warn that PMSCs are also themselves increasingly seen as targets. ${ }^{189}$ However, PMSCs are still apparently preferred to the Multinational Force (MNF), which due to its status as a primary target is to be considered 'a last resort to meet critical humanitarian need'. Local guards are apparently preferred to international ones as they might increase acceptance of humanitarian security needs. However, according to von Boemcken, the more dangerous the environment and the higher the risk, the more humanitarians seem to prefer large international PMSCs to local security. ${ }^{190}$ New guidelines were developed after the 2007 Security Council Resolution 1770, which underscored the humanitarian dimensions of the UN mandate. These guidelines reflect that the highly insecure environment in Iraq has eventually required the United Nations to rely on the overall security umbrella of the MNF-I. The exceptionality of the circumstances under which armed guards should be used thus appears to be relaxed considerably. Armed escorts and military assets should be utilised on a case-by-case basis and 'limited to the extent and duration necessary to undertake required assistance' ${ }^{191}$ Like most of the guidelines reviewed, they offer little real guidance for when and especially how to cooperate with PMSCs. The document simply confirms that agencies themselves will decide what to do in order to be able to operate within adherence to the DSS, Security Council resolutions and the primary humanitarian imperative. ${ }^{192}$ 
The 2008 civil-military guidelines for Afghanistan also recognise humanitarian PMSC reliance and assume a similar approach to the 2004 Iraq guidelines. Armed protection should be avoided or preserved for critical humanitarian need situations. A 2007 security report issued by the DSS stated, however, that the areas classified as 'Extreme Risk/Hostile Environment' and with restricted access to programmes had risen steeply to cover a third of the country. ${ }^{193}$ If the guidelines were abided by in practice, this would mean that the $17 \mathrm{UN}$ agencies, programmes and funds operating in Afghanistan by 2007 would have very little access to populations. The threats to UN personnel were especially tangible after the senior Taliban commander in the south was reported to have stated: 'we are attempting to target everyone that works for the UN and are determined to target all UN organisations and branches, considering them similar to US organisations' ${ }^{194}$ Statements like these arguably indicate that in some operating environments like parts of Afghanistan and Iraq, 'extreme precautionary measures' such as PMSC security services may be becoming more routine than exceptional. Humanitarians are in general increasingly experiencing constraints to their operating space in difficult missions and are accordingly faced with dilemmas that involve making tough security decisions. These choices could perhaps be made simpler by introducing clear and functional guidelines when considering the different options at hand. The lack of UN guidelines and clear policies towards PMSC contracting may be interpreted as an indication of varying policies and approaches within the organisation, making one common approach too difficult to achieve in practice.

\section{Peacekeeping perspectives}

While there are arguably few prospects of UN blue helmets being substituted by PMSC personnel in the near future, a range of less comprehensive PMSC services are likely to be increasingly procured. These may include support and logistics, guarding, demining and SSR-related services, and do merit a coherent political approach from the DPKO and DFS. None of the departments communicates much regarding PMSC contracting habits or the challenges PKOs face as a result of frequent PMSC presence in the operating environments where UN missions are present. Most agents operating in conflict and post-conflict environments face 
issues of how to coordinate or at least coexist with such elements, if only to avoid association with such companies. UN missions need directions and guidelines on how to integrate their own commercial partners, or alternatively how to disaggregate them from UN staff, as well as on how to relate to PMSCs serving other clients present in the mission. But a 2010 DPKO report on civil-military coordination in UN integrated peacekeeping missions makes no references to private commercial security actors whatsoever. This does of course not mean that no such guidelines exist. But in general the DPKO appears unforthcoming in terms of communicating how it tackles issues related to PMSCs, and even less so regarding its own dependency on such companies.

While quite a large share of the services procured by the DPKO and DFS may be fairly uncontroversial, the companies may not be. The UNMAS website lists G4S Ordnance Management (ArmorGroup Mine Action), Olive Group and EOD Technology among its implementing partners, all of which also supply armed security in war zones. Recently, EOD and ArmorGroup have both been identified as companies which have relied on personnel linked to the Taliban. ${ }^{195}$ However, when asked about non-technical selection criteria for partners, the public information officer of UNMAS offers no response. Overall, very little information is given regarding DPKO or DFS approaches to PMSC contracting, perhaps reflecting a lack of clearly stated policies.

Even though most of the services used by the DPKO and DFS may be routine support (logistics, maintenance, etc), these can be combined with security services, risk assessments or training services which may require firm guidelines. According to a DFS official, field missions apparently tend to shy away from contracts where one company supplies a multitude of services, such as security. However, as discussed above, it does happen, as in MONUC ${ }^{196}$ and the African Union/UN hybrid operation in Darfur (UNAMID), where PAE supplied a variety of more or less integrated services. ${ }^{197}$ In many cases, however, security may only be supplied in order to sustain other contracted services and hence not be demanded directly by the UN client. Arguably this nonetheless becomes a matter of indirect UN security contracting when such personnel are contracted to perform services for a UN entity.

The Best Practices Unit, a DPKO and DFS integrated and shared capacity, refers queries to the general UN Procurement Manual and Global 
Marketplace when asked about guidelines for PMSC contracting. ${ }^{198}$ Another DFS official claims that to their knowledge there is 'no contracting policy specific for security contracts in DPKO', ${ }^{199}$ which is further confirmed by sources in the DSS. ${ }^{200}$ Perhaps testimony to the inadequacy of such policies, a UNOPS official in contrast states that specifications for security-related procurement within UNOPS exist but are not open to public insight. ${ }^{201}$ There is hence a certain internal ambiguity as to whether applicable guidelines and selection criteria, or policies in general regarding DPKO and DFS contracting for PMSC services, actually exist. Presumably, guidelines drafted particularly for the contracting of PMSCs to perform armed security services are non-existent.

The practice of buying security itself is not dismissed by the DFS: in fact it confirms that PKO missions all procure security. However, whether DSS security professionals are involved in those processes is doubtful. An official of the Field Procurement Liaison Team at the DFS states that 'One thing is definite is that outsourcing of some security services in field missions is allowed and requires interface between the mission and the Department of Security and Safety [sic] of the Secretariat. ${ }^{202}$ Most of the services involve local companies providing unarmed security to protect premises and property; international companies are also used, but mostly for consultancy. ${ }^{203}$ UNOPS officials also indicate that the procurement of security services is done according to distinct routines which involve the security competency judgements of the DSS. ${ }^{204}$ To outsiders, for the DSS to have a say in security contracting and the specification of requirements seems no less that natural. Somewhat surprisingly, however, officials within the DSS deny that there are any such procedures in place for the DFS to involve the DSS in PMSC contracting whatsoever. Rather, on an informal basis country security advisers may provide advice locally, but it is claimed that the DFS has, in fact, been known not to seek the advice of the DSS. Cooperation between the DSS, DPKO and DFS has taken place in particular and extraordinary environments such as Iraq and Afghanistan, but as yet this is not the convention, and mechanisms for such cooperation are still non-existent. ${ }^{205}$ The discrepancy between what is often stated as the official procedures and what seems to be carried out in practice is thus significant. It furthermore indicates that although the DSS may be recognised as able to provide guidance on PMSC contracting, this is not taken advantage of, perhaps due to competitive relations between the different parts of the 
organisation (even within the departments of the Secretariat), or due to preferences for a more ad hoc approach to this type of contracting. In any case it goes to show that PMSC contracting is not handled in a coherent manner, or according to established procedures.

In terms of PKOs and their management, there are clear indications that some of the more powerful donor states do have policy preferences, particularly in cases where there appear to be cost-saving incentives. In order to improve cost-efficiency, the United Nations has in the past been strongly encouraged to follow the US example and expand its outsourcing practice to what apparently includes front-line roles. In a US Senate appropriations bill regarding US contributions to international peacekeeping activities in 2005 , the private sector solution to cutting UN peacekeeping costs appears only semi-optional:

The Committee is aware that, in some cases, private companies can carry out effective peacekeeping missions for a fraction of the funding the United Nations requires to carry out the same missions. At a minimum such companies should be utilized to supplement the number of blue berets and blue helmets which, in these turbulent times, the United Nations is having a difficult time recruiting. The United Nations can no longer afford to ignore the potential cost-savings that private companies with proven records of good service and good behavior can offer. ${ }^{206}$

UK influence is likely to lead to similar recommendations. The UK and the United States are both prime examples of countries which have resorted to large-scale outsourcing and privatisation of military establishments. ${ }^{207}$ These two countries also have the largest and most advanced private security and military industries, and are thus likely to benefit from UN outsourcing. ${ }^{208}$ Other states with less influence may have objections to such practices for normative reasons, and may thus oppose outsourcing of security functions or peacekeeping duties. Governments such as South Africa and France have been particularly unwilling to include the private sector in peace operations. ${ }^{209}$ Several developing states' governments have also voiced concerns about PMSCs in terms of potential violations of national sovereignty and potential negative effects of security personnel turning to international PMSC work. Close conceptual proximity to mercenaries, the past combat operations of Executive Outcomes and Sandline International in parts of Africa and perceptions of PMSCs as agents who commit human rights abuses and make a profit on war and human suffering lead many UN member countries to maintain a sceptical attitude 
towards the United Nations using PMSCs at all. Strong normative disincentives against outsourcing security functions in general may have led some member states to oppose increased PMSC reliance in multilateral operations.

Furthermore, national interests may invoke resistance to PMSC deployments. Some troop-contributing countries may regard increased UN reliance on PMSCs in peace operations to run counter to their own economic interests if it threatens to replace their contributions to UN peacekeeping. Nigeria, for example, has maintained a clear anti-mercenary line and is at the same time one of the major troop-contributing countries for UN peace operations. Seconding police or military personnel may be rewarding, as it provides useful military and police training to these forces, and may serve to keep troops in active duty but out of the domestic political scene. Monetary compensation may also be a motivating factor for contributing personnel to UN missions. In some cases member states have been known not to pay their soldiers the full amount received from the United Nations, thus effectively making a profit from participation in UN operations. In such cases, one could argue that there is a certain resemblance between paying for PMSC services and paying for national PKO contributions.

Many countries appear tacitly to approve of private security contracting as they themselves face security challenges in countries where they maintain a commercial, diplomatic or military presence, and rely on such services to protect embassies or personnel. In Afghanistan, for instance, all foreign embassies are believed to be protected by PMSCs irrespective of the individual countries' domestic policies on PMSCs. ${ }^{210}$ Member states also may not be consistent in their approaches. What is communicated in the General Assembly or the Security Council may not be reflected in NATO, European Union or African Union contexts, and/or may diverge from the approach they take regarding their implementing agencies. Such 'pragmatism' plus the fear that critique will result in demands for enhanced state contributions may explain why member state focus on the UN's deployment of PMSCs is lacking. 


\section{Procurement perspectives}

Two UN procurement agencies, UNOPS and the UN Procurement Division (UN/PD), appear increasingly to handle the procurement of security services. UNOPS mainly does procurement for the agencies, programmes and funds, while UN/PD executes the procurement policies decided by the Secretariat and individual missions. ${ }^{211}$ For example, UNOPS provides other parts of the organisation with services ranging from entire projects to temporary filling of gaps in operational capacity. In this way, suborganisations of the UN can outsource their procurement and thus 'supplement their own capacities, reduce risks, improve speed, quality or cost-effectiveness'. ${ }^{212}$

UNOPS manages procurement and tendering on service contracts for a wide range of operational activities. Examples include census and election support services, support for environmental and health programmes, physical infrastructure and public order and security. Common to these categories is that they often require a combination of specialised services and equipment along with support personnel, logistics and quite often also security services. According to one UNOPS procurement specialist, the volume of security services has increased substantially over the past couple of years, a development which can be traced to the increasingly difficult operating environments where UN organisations are present. One indication of increased threat levels is the recent dramatic increase in procurement of armoured vehicles. ${ }^{213}$ In the case of security or goods contracting, the DSS handles specifications of the required service on an ad hoc basis and UNOPS or UN/PD handles tendering and acquisitions. While UNOPS holds that the DSS should be involved in most specialised security procurements, many calls for specifications in reality go unanswered, as the DSS does not have the time or resources to provide these systematically. ${ }^{214}$

Accordingly, UNOPS manages contracts for some of the key PMSC service areas on behalf of various UN agencies. The PMSC contracting carried out by the specialised procurement agencies should be held to higher standards than the ad hoc contracting done by agencies as described above. Such processes should expectedly also be far more traceable and transparent than decentralised and ad hoc contracting. Several issues influence the transparency of PMSC deployment in this context. Firstly, PMSCs are not entirely easy to discern from other companies in the reports, 
as companies are only listed by name. The United Nations has a policy of contracting primarily with locally registered companies or companies that have local partnerships, ${ }^{215}$ which may mean that most security-related contracts go to local providers, local branch offices which may register under different names or local companies acquired by larger international ones. Extensive subcontracting in one or more layers also tends to hamper easy access to information. Another limitation on transparency relates to the deficient information actually available online and in statistical reports. In many instances UNOPS does not reveal the supplier of security services, 'due to security reasons'. Service specifications are also often intentionally kept minimal. One illustrative example from the UNOPS online project database is procurement of demining services to the UN peacekeeping operation in Chad. The United Nations itself funds the project, worth more than US\$4.5 million, and the suppliers of demining services are listed as from the UK but names are withheld. In this way observers are kept in the dark on whether such contracts go to NGOs or PMSCs. Another example is the procurement of personal security details (bodyguards) for the UNHCR in Iraq. While the service type is specified, UNOPS fails to list any contract awards whatsoever. While it is highly probable that the supplier(s) in this case are international PMSCs, they could also be local companies or other actors. ${ }^{216}$ According to UNOPS officials, only the contracts of individual consultants should be exempt from public scrutiny, and while dissemination of partial information may be justified by security concerns, these examples illustrate that in reality 'complete transparency' is not practised as yet.

Lacking transparency on individual contracts and contracting patterns hampers a thorough understanding of the magnitude and scope of PMSC contracting by UN missions or agencies. What does seem clear is that there are gaps in the UN's operational capacity in the field which are frequently filled by the commercial security sector. According to a UNOPS report, services pertaining to the miscellaneous category 'politics, peacekeeping and mine action services' totalled more than US\$130 million in 2009, while more than US\$44 million was spent on security services that year. ${ }^{217}$

Proper selection criteria and due diligence procedures are vital when choosing business partners for service contracts potentially requiring the use of force. Both UN/PD and UNOPS do apparently carry out independent market research to identify qualified providers and determine competition, capabilities and prices. ${ }^{218}$ UNOPS runs financial checks on potential supplier 
companies and checks ownership structures and holdings, ensuring for example that companies are not owned by criminals or terrorist organisations or involved in the production of mines, guns, etc. ${ }^{219}$ But neither UNOPS nor UN/PD in their otherwise detailed procurement manuals communicates that any special conditions apply to companies supplying security or armed services, ${ }^{220}$ nor are there service specifications to be used when contracting for security services. Accordingly, cooperation is needed between the DSS, legal capacities and procurement specialists to devise sufficient and substantive criteria, specifications or restrictions for the procurement of PMSC services. The agreed terms and selection criteria should then, as far as possible without compromising security, be subjected to considerably more transparency.

In spite of PMSCs operating with client confidentiality clauses, UNOPS has reportedly not experienced difficulties assessing past performance when selecting PMSCs for contracts. According to UNOPS officials, names of companies can potentially be checked with other UN entities or local police in the country where the company is registered. ${ }^{221}$ However, in many UN operational contexts, local police may not be the best source of reliable information on past performance of PMSCs. In complex environments such as those in Afghanistan or Iraq, objective information is no guarantee and several companies have been known to undergo frequent changes in names, ownership structures and corporate affiliations, which altogether seriously impair access to reliable information. In such situations UN agencies with PMSC contracting experience could potentially be very valuable sources of information simply by sharing experiences. However, according to one UN official, the United Nations currently has no established routines for 'cross-debarment', but UNOPS, UN/PD and other agencies may share information informally. ${ }^{222}$ Valuable experience and lessons learned thus appear largely unexploited so far.

To ensure that companies comply with general standards, the UN/PD maintains a roster of registered vendors in accordance with the UN Procurement Manual ${ }^{223}$ and UNOPS maintains a database of its approved companies. In addition, some companies have voluntarily registered as members of the Global Compact, Kofi Annan's initiative to make business adhere to some fundamental norms reflecting human rights, labour rights, environmental sustainability, etc. To maintain standards over time, companies may be removed or suspended from the UNOPS database, the 
UN/PD vendor list or the Global Compact's list of participants. UN/PD vendors may be suspended for technical or performance-related reasons by a vendor review committee, or for 'ethical reasons' by a senior vendor review committee. ${ }^{224}$ Guidelines for ethical behaviour can be found in the UN Supplier Code of Conduct, as well as in procurement manuals. These require general adherence to internationally proclaimed human rights, and UN conventions on forced labour, corruption and the environment. A somewhat narrower understanding of improper conduct is reflected in the 2010 edition of the UNOPS Procurement Manual, which states that the extreme case of unethical behaviour is when suppliers engage in corrupt practices'. ${ }^{225}$ In the case of armed services, such an understanding of ethical behaviour does little to ensure that UNOPS only conducts business with responsible suppliers with no unethical track records or companies which respect international human rights and local laws. To ensure that the United Nations only contracts with high-quality PMSCs and that unlawful behaviour is reported to local law enforcement, proper reporting procedures between the local mission leadership, the DSS and the procurement agency should be established to manage reports of improper contractor conduct, criminal offences, etc. In sum, the guidelines and practices shared by UNOPS appear insufficient to deal with complex security contracting where commercial agents are hired to protect lives, assets and premises.

There may also be reasons to doubt the quality control inherent in these list systems. In fact, Titan Corp. was still on the 2005 UN list of approved suppliers despite being linked to the misconduct in the Abu Ghraib prison in Iraq in 2004 and having been under investigation by the US Justice Department Securities and Exchange Commission for bribery charges in five countries. ${ }^{226}$ Similarly, in Afghanistan the United Nations apparently continued contracting with the US company US Protection and Investigations even after is was known that it had partnered with Northern Alliance military commanders like General Din Mohammad Jurat, who provided soldiers to the company, and that the company's owners were federally indicted for fraud in the United States. ${ }^{227}$

Similarly, the selection routines sketched out above and the potential sanctions have proved inadequate in ensuring that responsible contracting is done with PMSCs. This is largely due to the tendency for PMSCs to subcontract parts of their contracts, which places very high demands on 
oversight and vetting mechanisms. According to a US Senate report, in mid2008 UNOPS hired ArmorGroup Mine Action (AGMA) to conduct mine clearance in Herat province in Afghanistan. AGMA in turn hired a warlord with close ties to the Taliban, referred to as ' $\mathrm{Mr}$ White II', to provide security guards and vehicles. The warlord was later killed in a US military raid on a Taliban meeting along with seven other men employed as security guards by either AGMA or ArmorGroup. AGMA nevertheless subsequently hired the warlord's brother and, despite mounting doubts about his loyalty, kept him employed on the UN contract as a security provider until the contract expired in December 2008. ${ }^{228}$ This case illustrates the need for far better quality control and strict vetting procedures. The United Nations should draft contracts in such a way that it may terminate them if insufficient vetting or other detrimental conditions are exposed, e.g. by including the ICOC in the contract. UN contracting capabilities could also be improved by closely monitoring contracts and better communication routines.

Whether it is due to companies being registered in the procurement portal, a result of pre-qualifications, preference for companies which have local partnerships, personal preferences or connections, urgency, or a combination of these factors, some PMSCs feature prominently in UN contracts. ArmorGroup/G4S and its predecessor DSL, Gurkha-based IDG Security and G4 Risk Management have frequently conducted business with the United Nations. Other common partners include DynCorp, Global Risks and PAE. The 2010 list of approved UN/PD suppliers features a range of both British and US companies, including Aegis Defence Services, Gray Security Services, Hart Security UK, Specialist Gurkha Services, MPRI Inc., Steele North America, Olive Group and ArmorGroup Training. ${ }^{229}$ While a few member states would most likely embrace this list, others would maintain a more sceptical attitude towards the United Nations utilising a category of companies which many other member states regard as contentious.

\section{Human rights perspectives}

The clearest voice on the topic of private military and security companies in general has come from the special rapporteur and later the UN Working Group on the Use of Mercenaries as a Means of Violating Human Rights and 
Impeding the Exercise of Rights of Peoples to Self-Determination. The working group's mandate was established in July 2005 by the UN Commission on Human Rights and succeeded that of the special rapporteur. The position of special rapporteur was first established in 1989 and held by Enrique Bernales Ballesteros until 2004. Ballesteros largely equated the early PMSC industry with mercenaries, and warned that PMSC reliance had detrimental consequences for national self-determination and could also impair basic human rights for populations. ${ }^{230}$ The views held by the special rapporteur have been described as heavily influenced by a 'puritanical' normative position against mercenary use that essentially obscured the facts about private military action. ${ }^{231}$ Ballesteros failed to distinguish between mercenaries who supported secessionist groups in Katanga and Biafra in the 1960s and 1970s, and companies such as Executive Outcomes and Sandline International, which were hired in support of sovereign customer states. ${ }^{232}$

The subsequent special rapporteur, Shaista Shameen, assumed a somewhat more pragmatic approach, acknowledging that the United Nations relied on PMSC services from time to time and calling on the industry to engage in self-regulation and standards setting. ${ }^{233}$ Shameen's short term as special rapporteur ended with the establishment of the working group in 2005. The working group has in recent years placed a particular focus on PMSCs and made several country visits to (among others) Afghanistan and the United States to monitor the industry, which have produced important empirical knowledge. Although the working group appears divided, its reports have reflected a view largely consistent with that of Ballesteros: PMSCs 'represent a new form of mercenarism' ${ }^{234}$ Perhaps in contrast with its name, the focus of the working group appears to remain largely on the implications of PMSCs on the state monopoly of violence, and somewhat less on human rights violations per se. Illustrative of this perspective, to address the increasing prevalence of PMSCs the working group has continued to urge countries to ratify the largely unsuccessful International Convention against the Recruitment, Use, Financing and Training of Mercenaries. The 1989 convention has been ineffective in several respects. First of all it suffers from very low support from member states, taking 12 years to enter into force. ${ }^{235}$ Secondly, the convention has not prevented the growth in mercenary activities reported around the world. ${ }^{236}$ And finally, the convention offers a definition of a 
mercenary which is highly ambiguous even in terms of traditional mercenary forms, and largely inadequate to cover corporate security outfits. Largely due to these limitations and faced with an explosion in PMSCs, the working group was subsequently tasked by the Human Rights Council with preparing elements for a possible draft convention to regulate PMSCs. ${ }^{237}$

On this basis, the Working Group drafted a convention to regulate PMSCs, which they presented to the $15^{\text {th }}$ Session of the Human Rights Council. The 2009 Draft International Convention on the Regulation, Oversight and Monitoring of Private Military and Security Companies stipulates various ways states should take responsibility for PMSC activities. It emphasises state responsibility to regulate and monitor the industry, establish licensing regimes and draft laws that would hold companies legally accountable. The convention aims to have states commit to a minimum global standard for regulation of PMSCs, and spells out certain essential functions that states should agree not to outsource to private entities. These include waging war, combat operations, taking prisoners, espionage, intelligence gathering, police powers and the interrogation of detainees. $^{238}$ The convention also aims to establish an avenue of redress to potential victims of human rights abuses by PMSCs. In an effort to give effect to the convention, the draft entails the creation of an international committee to maintain international oversight of state initiatives and measures implemented to regulate PMSCs. The committee would also be tasked with mediation between states where human rights violations are reportedly committed by PMSC personnel, and the home state or contracting state of that company. As a means to prevent human rights abuses, the convention points to buttressing the state monopoly of legitimate use of force, territorial sovereignty and non-intervention norms. The draft convention thus continues to underscore the importance of reinstating the state as the main locus of action regarding the control of PMSCs.

While a useful starting point for discussion, the draft convention suffers from a series of weaknesses. It largely fails to take into account the inability of quite a few member states to commit to the convention due to their limited state capacities. Weak or failed states which cannot provide security to citizens, or which lack territorial control, are likely to face severe obstacles fulfilling the obligations of the convention. Another weakness 
concerns the unlikelihood that states, including the more influential ones, will welcome their outsourcing policies being dictated to them, effectively reducing the probability that the main supplier and consumer states will ratify the convention. Without the signatures of key client states, such as the United States and UK, chances are that the convention might share the fate of the 1989 Mercenary Convention and become largely irrelevant in guiding security practices.

The UN Office of Legal Affairs has stated that the United Nations would not be party or subject to international conventions. Still, it is striking that in dealing with the practice of hiring PMSCs in zones of conflict or humanitarian operations, the draft convention fails to address properly UN reliance upon PMSCs. The document barely touches upon the fact that the organisation is itself a frequent PMSC customer and carries its own responsibility for contractor adherence to international humanitarian law and respect for human rights. This omission becomes particularly problematic as the convention also envisions a UN organ to investigate potential reports of human rights violations, and subsequently impose 'appropriate disciplinary and penal sanctions'. ${ }^{239}$ A proper elaboration on how conflicting interests and roles should be avoided in this respect is essential, not least to give the respective control organ the needed authority and credibility. In fact, a UN-led international control and enforcement mandate may have a somewhat hollow ring to it since the United Nations has not been able to solve its own accountability problems in peace operations. For instance, UN peacekeepers are supposed to be investigated, tried and convicted of crimes committed on missions in the peacekeeper's country of origin. However, this does not always happen and the arrangement has been unable to guarantee the accountability of peacekeepers. As the United Nations itself does not have the power to discipline peacekeepers, promises to hold non-state PMSCs accountable may not be sufficiently convincing.

In sum, while it may not be within the working group's mandate to assess the UN line of policies, action or attitudes in terms of PMSC contracting, this body would inspire more confidence if UN use were taken into account. The draft convention offers few applicable solutions and accordingly appears a largely normative and prescriptive document. The draft seems to have had few practical or political implications thus far, other than remaining a topic of discussion by the open-ended 
Intergovernmental Working Group (IGWG), established in November 2010 by the Human Rights Council to consider the possibility of elaborating an international regulatory framework for PMSCs. Furthermore, the issue of UN contracting practices was initially taken up by the Inter-Agency Security Management Network and DSS, a forum where senior security managers of agencies meet with the DSS to discuss security policies.

At the intergovernmental level, consideration of the need for a convention has shifted away from the Working Group on Mercenaries and on to the IGWG whose mandate includes considering 'the option of elaborating a legally binding instrument on the regulation, monitoring and oversight of the activities of private military and security companies' ${ }^{240}$ The International Code of Conduct for Security Services Providers and the Montreux Document are considered potential parts of such an instrument, but it is emphasised that these measures must be enforced, not left to selfregulation, as they may be exploited as mere window dressing. ${ }^{241}$ In general the initiatives spearheaded by the UN working group on mercenaries have attracted support from a range of developing countries, notably Cuba and South Africa, but have largely failed to receive support from Western countries, which host most of the PMSC industry. Indeed, the IGWG initiative was inaugurated with a striking lack of support by Western states; apart from Russia, no Western country voted in favour of the establishment of the new working group. This may be due to the strong scepticism towards PMSCs conveyed by the working group in the past, but also due to some countries' perceptions that the matter of PMSC regulation is not primarily a human rights issue. ${ }^{242}$ Notwithstanding their skepticism towards the IGWG process, governments from the Western European and Others group engaged with the first session of the IGWG held in May 2011 and in the interactive sessions sought to emphasise the 'possibility of an international framework' aspect of the IGWG's mandate rather than on the possibility of a draft convention. ${ }^{243}$

To sum up, first, the issue of PMSCs is particularly sensitive regarding security services, but to date the DSS has not been given a significant role in devising procedures or recommendations for security contracting, although there is a chance that this may change if current policy proposals are implemented. Second, within the humanitarian segments of the United Nations, PMSCs may be even more controversial as they may at times work against the security approaches preferred by most humanitarian actors. Yet 
the decision on whether or not to buy PMSC services seems to be left to each organisation or to field personnel. No coherent guidelines or best practices have been agreed within the UN humanitarian community. Third, from a peacekeeping perspective, pragmatism seems to be prevalent as a guiding principle. There are, however, insufficient procedures for safeguarding contracting within these operations and an unclear policy regarding PMSC contracting in general. In the context of peacekeeping, the political preferences of influential member states also impact on UN practices. The United States in particular has encouraged increased use of PMSCs, while some developing countries have countered such strategies. Fourth, proper guidelines are lacking for UN procurement. Procurement agencies within the United Nations increasingly handle tendering for security services, including those won by PMSCs. However, proper cooperation between security specialists at the DSS and the procurement specialists is not established. In general few specific demands or due diligence procedures appear to be in place for PMSCs, and UNOPS appears to treat security contracting as it would any other service area. Finally, the UN system has so far provided little clarity on its own PMSC contracting practices. The strongest voice has been the UN Working Group on the Use of Mercenaries, an organ which, in contrast to many of the organisations that hire PMSCs, is not tasked with implementing policies in the field. 


\section{CONCLUSION}

This paper attempts to shed light on UN contracting with private military and security companies. The combination of expanded scope for action and deteriorating working conditions for both humanitarians and peacekeepers has put pressure on an already strained organisational apparatus. The paper argues that these factors have created voids in the operational capacities which are increasingly filled by service contracting, including PMSC services. By critically examining the UN's use of PMSCs the paper highlights a particularly opaque practice which so far has been little discussed. It is important to be aware of how the commercialisation of security has embedded itself into the day-to-day running of the United Nations and its efforts to promote development and peace. While much attention has been paid to security services, PMSCs also supply a range of other services to the United Nations. These include support and logistics as well as more specialised services such as civilian police, demining and intelligence. Empirical examples show that the United Nations has not only bought services which traditionally have been in short supply (such as demining or logistics), but also that in-house capacities are supplemented with such personnel (security consulting). Finally, examples illustrate that even in areas where the United Nations itself plays a lead role (such as within DDR and SSR programmes), shortages or difficult contexts have required contracting personnel from the PMSC industry. The paper also illustrates that PMSC contracting is not an isolated practice carried out by particular members of the UN family; instead it appears to be a common practice of many of the agencies, funds, programmes, departments, country teams and local duty stations. 
Different and at times conflicting aspirations, such as national selfdetermination, individual human rights, economic development, preservation of the environment and the establishment of peace, may not always be mutually compatible. The United Nations and its member states understand and value them differently. In pursuing these goals the UN system is thus likely to face conflicting logics of consequences and appropriateness. ${ }^{244}$ Conflicting norms in fact appear to be incorporated into different aspects of the UN structure. The views expressed by the Working Group on the Use of Mercenaries stand in contrast to the more pragmatic approach of those securing staff and assets while maintaining operations in difficult operating areas. The paper thus illustrates that the multifaceted collective which makes up the UN family is little integrated and coordinated in terms of the PMSC question. The most obvious commonality is, unfortunately, a consistent lack of clear and articulated policies concerning the use of PMSCs. Complicating policy formation prospects is the perception that devising explicit policies and guidelines may be interpreted as an endorsement of the industry or the practice of using PMSCs, and that keeping things ad hoc is thus preferable. Certainly, the controversy both within the organisation and among UN member states has greatly contributed to hinder constructive debate.

While the United Nations has so far suffered from an underdeveloped, insufficient and incoherent approach to its PMSC deployment, there is still some recognition that common policies are needed, at least in terms of security contracting. One OCHA official contends that the United Nations is beginning to 'wake up' and there is in fact increasing attention paid to the issue within the humanitarian parts of the organisation. ${ }^{245}$ While this may be true in some respects or some divisions, other UN employees have suggested there is little incentive to regulate the practice as it may prove restrictive to the contracting process and delay operations. Considering the different approaches to PMSCs, there is little to suggest that devising new UN-wide policies on the matter is likely to go unchallenged. While the new policy suggested by the Policy Committee Secretariat on the basis of a DSS initiative (see above) may be welcomed in some divisions, it is likely to face considerable resistance in other parts of the organisation, and whether agreement and compliance can be achieved on such a sensitive issue is uncertain. Nevertheless, considering the diversity of actors involved, the new policy proposal will 
spur debate, and is as such a good start, even though it may take time to build consensus.

There have been calls in the past for the United Nations to take on a role in regulating the industry. The Human Rights Council has recently acted, establishing the IGWG to consider the need for an international regulatory framework. This government group could potentially propose a role for the United Nations organisation in conducting oversight of the PMSC industry. However, as long as the United Nations does not establish consistent and responsible policies for its own use of PMSC services, this makes it less likely that it, as an organisation, can take a lead on this matter. Furthermore, a lack of support for the IGWG initiative amongst some key states suggests that member states do not see the United Nations as the appropriate forum to dicuss this issue, let alone whether it is in their interest for the United Nations to take on such a potential oversight role. The existing elusive approach may be in the interest of some member states, allowing for flexibility in contributions to UN operations.

Irrespective of how much member states would value a UN role in regulating PMSCs, they need to become increasingly attentive to the conditions leading UN entities to outsource to PMSCs. Discussions of peacekeeping capacities cannot, as pointed out by the DPKO and the DFS, be divorced from current financial realities. ${ }^{246}$ While the new security management system is being put into effect, it is clear that the United Nations suffers from many years of inattention to, and underinvestment in, security. The resulting soaring security costs are felt across the system. The costs of complying with the minimum operating security standards are increasing and some agencies do not have the financial means to comply. ${ }^{247}$ Even the acceptance approach, often relied on by humanitarians, has lately been more costly as it increasingly requires substantial information campaigns. Security costs thus need to be taken into account when planning development and humanitarian projects in order to allow for longterm and stable security arrangements. The need for more permanent inhouse security capacity to protect UN staff and property should consequently be recognised by donors. In particular, the organisation must not only introduce a 'culture that embraces security as a common and shared responsibility', ${ }^{248}$ diffusing greater responsibility for security on to its general management and staff; it must also update and professionalise its approach to security management to reflect the increasingly complex 
environments in which the United Nations operates. Importantly, professionalisation does not necessarily mean increased use of commercial solutions, nor a system which reduces security to a matter of technicalities and costs. ${ }^{249}$ Rather it requires an approach which balances the need for specialised measures while still maintaining proper civil-military divisions.

In an ideal world, the United Nations would probably not buy PMSC services in the first place. However, in the current situation a more proficient and proactive approach to PMSCs should be beneficial not only to the United Nations but also to affected populations. The benefits potentially extend to other PMSC clients, as it would enable the United Nations to use its client leverage to set standards for PMSC performance. By becoming a responsible and smart consumer of PMSC services, the United Nations could influence the market for security in a positive way. One potential way of doing this is through endorsing the International Code of Conduct for Private Security Providers. ${ }^{250}$ This initiative should be of interest to the United Nations, which has long struggled with accountability issues for its own personnel in international operations. By integrating the ICoC into PMSC contracts, it grants the client liberty to terminate the contract in case of human rights breaches or violations of international humanitarian law enshrined in the code. This would represent a way of holding companies more accountable than contracting a non-signatory company. It would also go a long way in assuring that contracting is done with companies which are familiar with international humanitarian law. For the United Nations only to contract with signatory companies would also convey a message to the rest of the industry. While not a solution to all the problems and issues surrounding PMSC oversight, accountability and regulation, it would certainly represent an improvement to the ad hoc and often unconditional contracting which still seems prevalent within the UN system. Whether implementing the ICoC or choosing other solutions, the United Nations should establish a proficient template for contracts that dictates conduct and operating standards and goes beyond deferring liability from the United Nations in cases of misconduct or damage.

PMSCs and their impact on operating environments, monopolies of state violence, security policy-making, human rights, etc. are issues with which NGOs, international NGOs and member states increasingly grapple. The UN organisations can no longer afford not to have a position in the international discourse on PMSCs beyond the ban on mercenaries. 
Continued reliance on an ambiguous approach risks strategic incoherence, negative publicity and even legal liability due to unclear procedures and policies for PMSC contracting. ${ }^{251}$ Decentralised and ad hoc contracting, based on subjective judgement or superficial internet searches, for potentially lethal services should clearly be avoided. Hopefully, the DSS policy initiative will prepare the ground for skilled and responsible contracting and selection of only the most responsible and accountable companies on the market. Professional background checks and vetting are challenging but vital, and should be easier to accomplish if lessons learned from individual agencies' experiences and assessments of PMSC contracting are shared. Continued failure to share experiences will allow contracting companies' misbehaviour or mediocre performance to recur across the UN system. This is not to say that the United Nations should not analyse its practices and identify the needs most often covered by PMSCs in an attempt to utilise in-house capabilities or member state contributions better. However, quick fixes are most likely scarce and mostly unable to remedy organisational deficiencies. Reform is an ongoing process, and judging by the examples provided in this study, the practice of hiring PMSCs to do parts of a job seems already well established and is unlikely to cease.

Finally, while the UN flag in itself provides little protection in many operating environments, decision-makers should reflect on how adding privately procured personnel may impact upon longer-term security situations for UN staff, and whether there is a 'way back' when outsourcing security has become established practice. The United Nations should thus consider whether some tasks should remain the exclusive domain of UN personnel, and whether resources should be redirected in certain cases. In sum, PMSC deployment poses a series of dilemmas to the United Nations, some operational and others of a more principled/political nature. These should be comprehensively dealt with in order for alternatives to be identified, or in the case of PMSC contracting to ensure that this is done according to carefully considered procedures and practices which establish high standards of performance as well as clear-cut contractor accountability. 


\section{NOTES}

1 Peter Utting and Ann Zammit, 'Beyond Pragmatism. Appraising UN-Business Partnerships', Markets, Business and Regulation Programme Paper 1 (Geneva: UN Research Institute for Social Development, 2006), p. v.

2 From 2005 the share of system service procurement rose as a share of total procurement. In 2006 the share of services overtook that of goods for the first time. In 2009 the share of services surpassed that of goods by more than 7 per cent, representing the largest increase in the history of the UN annual statistical report. UNOPS, '2009 Annual Statistical Report' (Copenhagen: UN Office for Project Services, 2010), p. 3.

3 The policy proposal culminated in a paper titled 'The UN's Use of Armed Private Security Companies. Submission to the Policy Committee'. It was drafted by the Policy Committee Secretariat in consultation with the DSS, Policy Committee focal points, the UN Department of Management, the WFP, UNHCR, UNICEF, WHO, the UN Relief and Works Agency for Palestine Refugees and on the basis of discussions within the IASMN. Discussions were also held with the UN Working Group on the Use of Mercenaries. Interview with DSS official conducted on the condition of anonymity, May 2011.

4 PMSCs employ mainly former military personnel, and thus may convey military perceptions of risk and security solutions.

5 Swiss Federal Department of Foreign Affairs and the International Committee of the Red Cross, 'The Montreux Document' (Geneva: International Committee of the Red Cross/Swiss Confederation, 2008), p. 9.

6 It should be pointed out that this paper is not about guarding companies or private security companies providing 'regular' security services such as access control and security at airports, malls, offices and the like. The United Nations, as any other major organisation, company or government, buys these services in all countries where it operates. This paper focuses squarely on contracting with private military and security companies, which belong to a slightly different segment of the commercial security market.

7 This does not apply to the UN High Commissioner for Human Rights, who has defined a PMSC as a 'corporate entity which provides on a compensatory basis military and/or security services, including investigation services, by physical persons and/or legal entities'. Office of the UN High Commissioner for Human Rights, 'Draft International Convention on the Regulation, Oversight and Monitoring of Private Military and Security Companies', Geneva, 19 July 2009, p. 6.

8 According to Spearin, the IPOA's original raison d'être was 'to make the case for substantial private involvement in UN peacekeeping operations'. Christopher Spearin, 'Between Public Peacekeepers and Private Forces: Can There Be a Third Way?', International Peacekeeping, vol. 12, no. 2, 2005, p. 240.

9 See e.g. Christopher Spearin, 'UN Peacekeeping and the International Private Military and Security Industry', International Peacekeeping, vol. 18, no. 2, 2011, p. 196-209; Oldrich Bures, 'Private Military Companies: A Second Best Peacekeeping Option?', International Peacekeeping, vol. 12, no. 4, winter 2005, p. 533-546; Malcolm Patterson, 'A Corporate 
Alternative to United Nations Ad Hoc Military Deployments', Journal of Conflict \& Security Law, vol. 13, no. 2, 2008, p. 215-232.

See e.g. Deborah Avant, 'The Privatization of Security and Change in the Control of Force', International Studies Perspectives, vol. 5, no. 2, 2004, p. 153-157; Abby Stoddard, Adele Harmer and Victoria DiDomenico, 'The Use of Private Security Providers and Services in Humanitarian Operations', Humanitarian Policy Group Report 27 (London: Overseas Development Institute, 2008); James Cockayne, 'Commercial Security in Humanitarian and Post-Conflict Settings - An Explorative Study' (New York: International Peace Academy, 2006); Christopher Spearin, 'Humanitarian Non-Governmental Organisations and International Private Security Companies: The "Humanitarian" Challenges of Moulding a Marketplace', Policy Paper No. 16 (Geneva: DCAF, 2007).

Stoddard et al. (ibid.) and Cockayne (ibid.) do, however, provide empirical information on humanitarian contracting in general, stemming mostly from extensive interviewing. Private communication, anonymous DSS source, 2011.

'Moonlighting' here typically means working as a security guard on the side while being employed in e.g. law enforcement or within the military.

Employing local security personnel may impact on power dynamics, divert manpower away from a developing state sector or even create a parallel security structure, as claimed by Afghan President Hamid Karzai. Spearin, note 9 above, p. 200.

Advice and training are only procured infrequently, however, and a recent attempt by UNDP to buy security analytical services was stopped by member states. Anonymous DSS source, 2011.

Eric Prince, Blackwater's CEO, in February 2005 proposed the company could put together a 'quick-reaction force' to provide security for NGOs and 'deal with' the Janjaweed militia in Sudan's western region of Darfur. Graeme A. Hodge, 'Blackwater CEO Touts Private Peacekeeping Model', Defense Daily, 23 February 2005. The PMSC trade association, the IPOA, launched suggestions for some of its member companies to bolster both MONUC and the UN Mission in Sudan. 'Supporting the MONUC Mandate with Private Services in the Democratic Republic of Congo', IPOA Concept Paper, 2003, available at www.hoosier84.com/030201ipoa-drc.pdf; 'IPOA Support Operation to Monitor a Sudan Peace Agreement', IPOA Concept Paper, 2004, apparently no longer available.

Bures, note 9 above, discusses the pros and cons of potential large-scale outsourcing of UN peacekeeping. The IPOA-affiliated Peace Operations Institute suggests PMSCs should increasingly complement the United Nations in peace and stability operations worldwide. Christopher M. Rochester, 'A Private Alternative to a Standing United Nations Peacekeeping Force', White Paper (Washington DC: Peace Operations Institute, 2007). Similarly, Patterson suggests a contractor peacekeeping and intervention force under the auspices of an envisioned UN entity which he names 'the UN Directorate of Military Contracting'. Malcolm Hugh Patterson, Privatising Peace: A Corporate Adjunct to United Nations Peacekeeping and Humanitarian Operations (Houndmills: Palgrave Macmillan, 2009). While there are many unsolicited papers on similar ideas, none has been treated with much credence by the United Nations, nor seriously studied by it as a potential viable solution to many of the issues facing peacekeeping operations (anonymous DSS source, 2011). 
Spearin, note 9 above.

Interview with DSS official, May 2011.

Nina M. Serafino, Policing in Peacekeeping and Related Stability Operations: Problems and Proposed Solutions (Washington DC: Congressional Research Service, 2004).

See PAE, 'CivPol Description by Task Order', available at www.paegroup.com/career-justicesupport-description.

US Department of State, 'Peacekeeping Support in Africa', Contract no. S-LMAQM-03-C-0034 (2003), available at www.state.gov/m/a/ips/c35166.htm.

DynCorp, 'Programs', available at www.dyncorprecruiting.com/ext/progs.asp.

James Larry Taulbee, 'The Privatization of Security: Modern Conflict, Globalization and Weak States', Civil Wars, vol. 5, no. 2, 2002, p. 5.

See Paramount's homepage, available at www.paramountgroup.biz/en/solutions/ international-peacekeeping; Scott Firsing, 'America and UN Peacekeeping', Journal of International Peace Operations, vol. 7, no. 1, 2011, pp. 21-23 .

Cockayne, note 10 above, p. 9.

Christopher Spearin, 'Private Security Companies and Humanitarians: A Corporate Solution to Securing Humanitarian Spaces?', International Peacekeeping, vol. 8, no. 1, 2001, p. 28.

Tony Vaux, Chris Seiple, Greg Nakano and Koenraad Van Brabant, Humanitarian Action and Private Security Companies. Opening the Debate (London: International Alert, 2001).

Interview with DSS official, May 2011.

Stoddard et al., note 10 above, p. 19.

It should be noted that the UN security community considers Stoddard et al.'s study (note 10 above) flawed, and few UN agencies provided information for the study (anonymous DSS source, 2011).

Vaux et al., note 28 above.

Stoddard et al., note 10 above, p. 9.

Select Committee on Foreign Affairs, Private Military Companies. Ninth Report of Session 2001-2002 (London: The Stationery Office, 2002).

UNOPS, '2008 Annual Statistical Report on UN Procurement' (Copenhagen: UN Office for Project Services, 2009), pp. 259 and 208. ArmorGroup was acquired by G4S in 2008.

Hart Security, 'Selected Experience', available at www.hartsecurity.com/aboutus selectedexperience.asp\#un.

Sources supplying information on recent contracting practices in places like Afghanistan and Iraq have proven hard to come by and some of the information supplied for this section dates back some years. Due to the hostile environment in e.g. Afghanistan, suppliers of uncontroversial services such as road construction and repair and other construction are often withheld for security reasons. Mine action services are bought on a large scale but no supplier names are revealed in official UNOPS records. See UNOPS, 'Contract Awards', available at www.unops.org/english/whatweneed/pages/contractawards.aspx.

Damian Lilly, 'The Privatization of Peacekeeping: Prospects and Realities' Disarmament Forum, vol. 3, 2000, pp. 53-64.

Select Committee on Foreign Affairs, note 34 above, $\S 85$. 
Peter W. Singer, Corporate Warriors: The Rise of the Privatized Military Industry (Ithaca, NY: Cornell University Press, 2003), p. 182.

Ibid., p. 183; Alex Bellamy and Paul Williams, 'What Future for Peace Operations: Brahimi and Beyond', International Peacekeeping, vol. 11, no. 1, 2004, p. 192.

Pratap Chatterjee, 'Darfur Diplomacy: Enter the Contractors', Corpwatch, available at www.corpwatch.org/article.php?id=11598.

Select Committee on Foreign Affairs, note 34 above, Minutes of Evidence (Thursday 13 June 2002), Appendix 6, §80.

UNPROFOR covered Bosnia and Herzegovina, Croatia, the Federal Republic of Yugoslavia (Serbia and Montenegro), and the Former Yugoslav Republic of Macedonia.

Select Committee on Foreign Affairs, note 34 above, Minutes of Evidence (Thursday 13 June 2002), Appendix 6, §74.

Ibid., §75.

Ibid., §76.

Ibid., $\S 76$.

Ibid., §77-78.

Potential evacuation had also been part of the contract with PAE (interview with DSS official, May 2011).

Asia Foundation, 'TAF - Global Voter Registration \& Elections Process (VREP) in Afghanistan', available at http://asiafoundation.org/publications/pdf/382.

Ibid.

Andrew North, 'Afghan Election Notebook 3 - Zabul Badlands', BBC News, 29 September 2004, available at http://news.bbc.co.uk/2/hi/south_asia/3700538.stm.

UN Secretary-General, 'Report of the Secretary-General to the Security Council on the Protection of Civilians in Armed Conflict', UN Doc. S/2001/331, 30 March 2001, §§9-45; International Commission on Intervention and State Sovereignty, The Responsibility to Protect (Ottawa: International Development Research Centre, 2001).

An expression of frustration of the headquarters focus is reflected in a comment made by former UNPROFOR commander Lewis MacKenzie: 'If you are a commander of a UN mission, don't get in trouble after five p.m. or on the weekend. There is no one in the UN to answer the phone!' Quoted in Duane Bratt, 'Preparing Peacekeeping for the 21st Century: Improving the UN Secretariat's Institutional Capability', Airman Scholar, III, 1997, p. 3. However, it should be pointed out that this was nearly 20 years ago and today the DPKO, DSS and UNICEF all have $24 / 7$ assistance teams.

UN General Assembly, Resolution 587276, 17 January 2005, section XI.

Lakhdar Brahimi, Towards a Culture of Security and Accountability. The Report of the Independent Panel on Safety and Security of UN Personnel and Premises Worldwide, 9 June 2008, p. 66.

The five UN security phases are precautionary measures, restricted movement, relocation, emergency operations and evacuation. Ibid., p. 52.

Ibid., p. 68.

Interview with DSS official, May 2011. 
'The Report of the Independent Panel on the Safety and Security of UN Personnel in Iraq', 20 October 2003, p. 1.

United Nations, 'Transcript of Press Conference by Deputy Secretary-General Louise Frechette at United Nations Headquarters, 13 January 2005', UN Press Release DSG/SM/242, 14 January 2005.

Brahimi, note 57 above, p. 3.

The integration of UNSECOORD into the new DSS has reportedly been problematic and resulted in internal mistrust and dissension within the DSS. Ibid., p. 35.

The organisation of the DSS has been subject to some criticism. However, somewhat ironically the structure was apparently based on a study by a 'specialised security firm' recruited by the Department of Management. UN Office of Internal Oversight Services, 'Comprehensive Management Audit of the Department of Safety and Security', Report of the Office of Internal Oversight Services, UN Doc. A/63/379, 26 September 2008, p. 7.

These are often referred to as the Safety and Security Services (SSS), but they were and still are not one single service. Rather, each office away from headquarters hired and deployed security officers based on copying those elements of the New York security service that they wanted. Different contracts, procedures, training and other doctrinal issues caused the voluntary collaboration of the different services under an ad hoc grouping called UNSSSNET. The creation of the DSS included the Division of Safety and Security Services, whose role is standardisation and facilitating cooperation among the SSS units which still report to their directors of administration or executive directors. Anonymous DSS source, 2011.

Sometimes also referred to as the Division of Headquarter Security and Safety Services.

Not to be mistaken for the Department of Field Support.

Brahimi, note 57 above, p. 3.

There are currently 17 countries where UN humanitarian or country team activities and a DPKO/DPA mission coincide, and one country security adviser manages the combined security. Anonymous DSS source, 2011.

Martin Barber, 'Private Security Companies and Humanitarian Assistance. The Privatization of Security: Framing a Conflict Prevention and Peacebuilding Policy and Agenda', Report of the Wilton Park Conference (London: International Alert, 1999), p. 35.

UN Office of Internal Oversight Services, note 65 above, p. 10.

The DPKO reportedly fields more than 1,400 professional field security coordinators and 2,500 locally recruited field security assistants. Brahimi, note 57 above, pp. 36-37.

UN Office of Internal Oversight Services, note 65 above, p. 6.

Brahimi, note 57 above, p. 42.

UN Secretary-General, Safety and Security of United Nations Personnel, UN Doc. A/55/494, 18 October 2000 , p. 8.

Ibid., pp. 8-9.

lbid.

'Report of the Independent Panel on Safety and Security of UN Personnel in Iraq', note 61 above, p. 19; UN Secretary-General, Strengthened and Unified Security Management System, UN Doc A/60/424, 11 October 2005, p. 7. 
Average time is reportedly now reduced to between three and six months. Anonymous DSS source, 2011.

High Level Committee of Management, 'Security and Safety of Staff', CEB/2008/HLCM/3, in Brahimi, note 57 above, pp. 37-39.

This is also related to peak needs, as the hiring of UN staff cannot be done routinely on a few days' notice and for a few weeks at the time. However, under certain circumstances and for emergencies, the United Nations can hire former employees on short-notice, short-term contracts, provided such personnel are available. Anonymous DSS source, 2011.

Vaux et al., note 28 above, p. 15.

UN Office of Internal Oversight Services, note 65 above, p. 15.

Brahimi, note 57 above, p. 42.

Ibid., p. 49.

Interview with DSS official, May 2011.

Interview with Fredrik Wallenberg, humanitarian affairs officer, Civil-Military Coordination Section, Emergency Services Branch, OCHA, Geneva, April 2010.

UN Secretary-General, note 79 above, p. 19.

Author's communication with John Millar, director of business development, ArmorGroup, July 2005.

There is only sparse information available on these contracts, and the location is often not stated. See the series of annual statistical reports on UN procurement produced by the UN Office for Project Services.

Alex Vines, 'Mercenaries and the Privatization of Security in Africa in the 1990s', in Greg Mills and John J. Stremlau (eds), The Privatization of Security in Africa (Johannesburg: South African Institute of International Affairs, 1999), p. 134.

Traci Hukill, 'Should Peacekeepers Be Privatized?', National Journal, vol. 38, no. 20, 2004, p. 1527. However, PAE currently does not supply any security services to the mission according to UN officials in the DRC. Also, PAE may have offered security mainly for the services of which it was in charge.

Control Risks, 'What We Do', available at www.control-risks.com/Default.aspx?page=334.

Until 2005 seven other headquarters in addition to New York, plus the International Tribunals in The Hague and Arusha, had their own security and safety services which operated independently, while other headquarters have had to rely on the services administered from New York.

Brahimi, note 57 above, p. 36.

'The Report of the Independent Panel on Safety and Security of UN Personnel in Iraq', note 61 above, p. 17.

Brahimi, note 57 above, p. 36.

Select Committee on Foreign Affairs, note 34 above, Appendix 1, §5.

See Dawn Media Group, 'WFP to Review Its Security Policy after Islamabad Blast', 7 October 2009, available at www.dawn.com/wps/wcm/connect/dawn-content-library/dawn/news/ pakistan/07-wfp-to-review-security-policy-after-islamabad-blast-ha-08. 
Colum Lynch, 'UN Embraces Private Military Contractors', Foreign Policy, 17 January 2010. Available at http://turtlebay.foreignpolicy.com/posts/2010/01/17/un_embraces_private_ military_contractors

UNOCA is the UN Office for the Coordination of Humanitarian and Economic Assistance Programmes relating to Afghanistan.

William Durch, Victoria K. Holt, Caroline R. Earle and Moira K. Shanahan, The Brahimi Report and the Future of UN Peace Operations (Washington DC: Henry L. Stimson Center, 2003), p. 86.

Collecting open-source intelligence as a basis for risk assessments on duty stations would be part of the responsibility of the (often vacant) field security officers.

105 Department of Peacekeeping Operations and Department of Field Support, A New Partnership Agenda: Charting a New Horizon for UN Peacekeeping (New York: DPKO/DFS, July 2009).

106 Walter A. Dorn, 'The Cloak and the Blue Beret: Limitations on Intelligence in UN Peacekeeping?', International Journal of Intelligence and Counterintelligence, vol. 12, no. 4, 1999, p. 442.

107 Susan Rice, 'Collective Response to Crisis: Strengthening the UN Peace Operations Capacity', UN Foundation Issue Paper, 2004, p. 2.

108 Jacob Aasland Ravndal, 'Etterretning i FN: Hvordan det umulige ble mulig', in Tore Nyhammar (ed.), Utfordringer og Strategi i Freds - og Stabiliseringsoperasjoner (Oslo: Abstrakt forlag, 2010), p. 106. Dorn, note 106 above, p. 433.

110 Simon Chesterman, 'Does the UN Have Intelligence?', Survival, vol. 48, no. 3, 2006, p. 154.

111 Department of Peacekeeping Operations, 'DPKO Policy Directive: Joint Operations Centres and Joint Mission Analysis Centres', Ref. POL/2006/3000/4, 1 July 2006 (New York: United Nations, 2006), §1.

112 Philip Shetler-Jones, 'Intelligence in Integrated UN Peacekeeping Missions: The Joint Mission Analysis Centre', International Peacekeeping, vol. 15, no. 4, 2008, pp. 518-519.

113 According to one commentator, about 70 per cent of the Pentagon's Counterintelligence Field Activity Unit is made up of contractors. Commercial companies also supply the majority of the personnel for the National Security Agency, the Central Intelligence Agency's National Clandestine Service and the National Counterterrorism Center, as well as at least 35 per cent of staff in the US Defense Intelligence Agency. Tim Shorrock, Spies for Hire: The Secret World of Intelligence Outsourcing (New York: Simon \& Schuster, 2008), pp. 11-15.

114 It is likely that these services were not supplied as a result of a predetermined contract, but rather resulting from an imminent need that arose in the field where the company happened to be present and where the United Nations had no choice of providers. See Christopher Kinsey, Corporate Soldiers and International Security (London: Routledge, 2006), pp. 84-85.

115 Colum Lynch, 'Private Firms Aid the UN on Sanctions: Wider Intelligence Capacity Sought', Washington Post, 21 April 2001, p. A15.

116 Singer, note 40 above, p. 183. 
Department of Peacekeeping Operations, 'Monthly Summary of Military and Police Contributors to United Nations Operations', available at www.un.org/en/peacekeeping/ contributors/documents/Yearly06.pdf.

Eirin Mobekk, 'Identifying Lessons in United Nations International Policing Missions', Policy Paper no. 9 (Geneva: DCAF, 2005), p. 1. Serafino, note 20 above, pp. 6-7.

Department of Peacekeeping Operations, 'DPKO Policy Functions and Organization of Formed Police Units in United Nations Peacekeeping Operations', DPKO/PD/2006/00060, 9 November 2006, pp. 3-4.

121 UN General Assembly/Security Council, 'Report of the Secretary-General on Peacebuilding in the Immediate Aftermath of Conflict', UN Doc. A/63/881-S/2009/304, 11 June 2009. See Mobekk, note 118 above, for a more complete account of the lessons learned.

This particular problem is a thorny issue, as illustrated by China's effort to train FPUs and contribute to peacekeeping operations. Such forces might not have the experience and skills, nor perhaps the incentive, to train police according to democratic standards.

Department of Peacekeeping Operations and Department of Field Support, note 105 above, p. 27. Ibid.

126 DynCorp, note 23 above.

${ }^{127}$ UNMIS, 'Provision of Training Courses on Peace Building/Keeping to UNMIS Personnel', available at www.un.org/Depts/ptd/eoi.htm. See Lynch, note 101 above.

According to Aegis, the company deployed some 780 personnel organised into 26 teams and supported by 41 armoured vehicles in the completion of the contract. Aegis webpage, 'Humanitarian Support Services', 2011, available at www.aegisworld.com/index.php/ humanitarian-support-services-2

130 UN Electronic Mine Information Network, available at www.mineaction.org/.

131 Christopher Spearin, 'Ends and Means: Assessing the Humanitarian Impact of Commercialised Security on the Ottawa Convention Banning Anti-Personnel Mines', YCISS Occasional Paper no. 69 (York: York Centre for International and Security Studies, 2001), pp. 6-8.

132 Phone interview with Cyrille Pernette, procurement specialist, Procurement Practice Group, UNOPS, 4 June 2010.

133 Africa Research Bulletin, 'SUDAN: AU Troops to Remain', vol. 43, 2006, pp. 16725-16726.

134 DSL was acquired by ArmorHolding in 1997, the new security division of which was called ArmorGroup. The company was again acquired by G4S in 2008.

135 Select Committee on Foreign Affairs, note 34 above, Appendix 1, §§6-7, Appendix 6, $\S 80$.

136 Millar, note 90 above.

137 UN Office of Rule of Law and Security Institutions, 'Security Sector Reform (SSR) Unit', available at www.un.org/en/peacekeeping/orolsi.shtml.

138 Department of Peacekeeping Operations and Department of Field Support, note 105 above, p. 27.

139 Select Committee on Foreign Affairs, note 34 above, Appendix 1, §§6-7. 
Asia Foundation, note 51 above.

Millar, note 90 above.

MPRI homepage, 2005, available at www.mpri.com/.

UN Secretary-General, 'An Agenda for Peace: Preventive Diplomacy, Peacemaking, and Peacekeeping', UN Doc. A/47/277-S/2411, 17 June 1992, p. 15.

It is beyond the scope of this paper to give a complete account of the logistics and support capacities of the United Nations. These service categories are vast and may include a large array of functions.

US Army, 'Commander's Handbook for Peacekeeping Operations (A Logistics Perspective)', Department of the Army Pamphlet 700-31 (Washington DC: Department of the Army), p. 2.

Panel on UN Peace Operations, 'Report of the Independent Panel on UN Peace Operations', UN Doc. A/55/305-S/2000/809, 2000, §169.

Durch et al., note 103 above, p. 93.

Some contributors argue that reimbursement rates do not reflect the costs inflicted upon the contributor for deploying higher-quality equipment or high-end expertise. The United Nations is to review the contingent-owned equipment, self-sustainment and reimbursement arrangements in 2011. Department of Peacekeeping Operations and Department of Field Support, note 105 above, p. 32.

Durch et al., note 103 above, p. 89.

Khalil Issa Othman, 'Report of the Joint Inspection Unit in Reforming the Field Service Category of Personnel in United Nations Peace Operations', UN Doc. A/57/78, 2002, §20.

Panel on UN Peace Operations, note 146 above, $\$ 140$.

Othman, note 150 above, $\S 12$.

UN Department of Field Support, 'Logistics Support Division', available at https://www.Isd.unlb.org/Pages/What\%20is\%20LSD.aspx.

UN News Service, 'New Strategy Set to Transform UN Support to Field Operations - Senior Officials', 30 July 2010. See also UN Logistical Base Brindisi webpage at www.unlb.org/procurement_activities.asp.

Singer, note 40 above, p. 183.

At least one contract was awarded by the US Department of State and was hence a case of indirect use. See ICI Oregon, 'Haiti: Peacekeeping Support', available at www.icioregon.com/haiti.htm.

Lilly, note 38 above, p. 55.

Retired general Ernest B. Beno, consultant with PAE, personal communication, 17 August 2005; Select Committee on Foreign Affairs, note 34 above, Appendix 6, $\S 80$.

59 This paper is unable to cover all units and aspects of the organisation. The humanitarian agencies, programmes and funds will not be dealt with individually or comparatively. More detailed studies are needed to cover this ground. The paper also does not cover the views of specialised agencies such as the International Maritime Organization, as the focus here is on those agencies and organisations involved in peace and development promotion. Interview with DSS official. Department of Safety and Security, Field Security Handbook, Annex O (New York: DSS, 2006). Annex $\mathrm{O}$ is accordingly included in an ongoing policy review. 
Interview with Chris Sanderson, director, Government Support Control Risks, 9 April 2010.

165 Interview with DSS official, May 2011.

166 See the US Department of State contract issued with DynCorp, Blackwater and Triple Canopy, available at http://r.m.upi.com/other/12216818791223.pdf.

167 Starr was noted to have defended Blackwater after the Nisour Square shooting of 17 people in September 2007, stating that 'essentially I think they do a very good job'. Quoted in BBC, 'Blackwater Contract Renewed', 5 April 2008, available at http://news.bbc.co.uk/go/pr/fr//2/hi/americas/7331972.stm.

168 UN Secretary-General, 'The Situation in Afghanistan and Its Implications for International Peace and Security', Report of the Secretary-General, UN Doc. A/54/613-S/2009/674, 28 December 2009. See note 3.

170 Abby Stoddard and Adele Harmer, 'Supporting Security for Humanitarian Action. A Review of Critical Issues for the Humanitarian Community' (New York: Humanitarian Outcomes, 2010), pp. 11-12.

171 Cockayne, note 10 above, p. 3.

172 UN Office of Internal Oversight Services, note 65 above, p. 5.

173 Deborah Avant, 'NGOs, Corporations and Security Transformation in Africa', International Relations, vol. 21, no. 2, 2007, pp. 149-150.

174 Von Boemcken holds that there is a trend for international NGOs to abandon the 'soft' model of security in favour of 'hard' deterrence models and that the acceptance-protection approach gradually transforms into protection-deterrence strategies. Marc von Boemcken, 'Liaisons Dangereuses: The Cooperation between Private Security Companies and Humanitarian Aid Agencies', in Thomas Jäger and Gerhard Kümmel (eds), Private Security Companies. Chances, Problems, Pitfalls, and Prospects (Wiesbaden: VS Verlag für Sozialwissenschaften, 2007), pp. 261-263.

175 Martin Randolph, 'NGO Field Security', Forced Migration Review, 1999, pp. 4-7, available at www.fmreview.org/FMRpdfs/FMR04/fmr401.pdf.

176 OCHA, 'About Us', available at http://ochaonline.un.org/AboutOCHA/Organigramme/ EmergencyServicesBranchESB/CivilMilitaryCoordinationSectionCMCS/tabid/1274/Default.as px.

177 The IASC is a forum for coordination, policy development and decision-making which has UN and non-UN humanitarian organisation members.

178 The guidelines were elaborated in cooperation with UNSECOORD and the DPKO, approved by the IASC and reviewed by the UN Office of Legal Affairs. OCHA, 'Discussion Paper and Non-Binding Guidelines on the Use of Military or Armed Escorts for Humanitarian Convoys', September 2001, p. 7. Ibid.

180 Ibid., p. 10.

181 Department of Peacekeeping Operations and Department of Field Support, 'Civil-Military Coordination in UN Integrated Peacekeeping Missions (UN-CIMIC), January 2010', §37, available at http://ochaonline.un.org/OchaLinkClick.aspx?link=ocha\&docld=1154389. 
182

183

184

185

186

187

Office of the UN Humanitarian and Resident Coordinator and Deputy Special Representative for the Secretary-General, 'Guidelines for UN and Other Humanitarian Organisations on Interacting with Military, Non-State Armed Actors and Other Security Actors in Iraq', August 2004.

189 PMSCs are sometimes considered a softer target than military forces and may thus attract more attacks than military components.

190 Von Boemcken, note 174 above. Some have also suggested that the United Nations prefers companies which rely on Gurkha personnel as they may attract less attention and be perceived as less biased than many Western nationalities. This is reflected in the advertising of Gurkha-based IDG Security, which states that 'our Gurkhas also empathise with rural and developing-world peoples and races which has enabled us to be readily accepted into many communities'. IDG, 'Training, Capacity Building and Consultancy', available at http://web.mac.com/idgsecurity/idg-security/Training_Services.html.

191 Office of the UN Humanitarian and Resident Coordinator and Deputy Special Representative for the Secretary-General, 'Guidelines for UN and Other Humanitarian Organisations on Interacting with Military, Non-State Armed Actors and Other Security Actors in Iraq, August 2008'. The 2008 guidelines are signed by the UN deputy special representative of the Secretary-General for Iraq and long-time PMSC industry analyst David Shearer.

192 Office of the UN Humanitarian and Resident Coordinator and Deputy Special Representative for the Secretary-General, ibid.

193 DSS Afghanistan, 'Half-Year Review of the Security Situation in Afghanistan, Topic Assessment 02/07'. 2007, available at http://media.mcclatchydc.com/smedia/2007/10/01/ 16/UNAMA_2007_Afghanistan.source.prod_affiliate.91.pdf.

194 Ibid.

195 In Afghanistan ArmorGroup has apparently repeatedly relied on warlords to recruit local guards. See Committee on Armed Services, US Senate, 'Inquiry into the Role and Oversight of Private Security Contractors in Afghanistan', 11th Congress, 2nd Session, 28 September 2010.

196 As of 1 July 2010, MONUC was renamed the UN Organisation Stabilization Mission in the Democratic Republic of the Congo (MONUSCO).

197 Phone conversation with Vevine Stamp, Field Procurement Liaison Team, Office of the USG for Field Support, 22 December 2010. 


\section{1, no. 2, 2007.}

210 Nicolas Van Praet, 'Garda Scrabbles to Stay in Afghanistan', Financial Post, 25 August 2010.

211 It should be noted that the larger specialised agencies most often do their own procurement, but it is beyond the scope of this paper to look at the specific procedures individually.

212 The entity now termed UNOPS was originally an integrated part of UNDP under different names. UNOPS, 'Partners', available at www.unops.org/english/whatwedo/partners/Pages/

${ }^{218}$ It is not within the scope of this paper to assess the complete procurement processes of UNOPS or UN/PD.

219 Pernette, note 132 above. 
220

Department of Management, Office of Central Support Services, Procurement Division, 'United Nations Procurement Manual, Revision 6' (New York: United Nations, 2010).

221 E-mail communication with Stee Asbjornsen, Guidance/Policy Planning, Peacekeeping Best Practices Section, DPKO, 20 September 2010. Ibid.

Ibid.; UN Global Compact, 'Frequently Asked Questions', available at www.unglobalcompact.org/AbouttheGC/IntegrityMeasures/Integrity_Measures_FAQs.html.

UNOPS, 'UNOPS Procurement Manual', Rev. 3, 1 May 2010, available at www.unops.org/ SiteCollectionDocuments/Procurement\%20docs/UNOPS\%20procurement\%20manual\%20EN .pdf, p. 17. See also 'UN Supplier Code of Conduct', Rev. 3, May 2007, available at www.un.org/depts/ptd/links.htm\#; UN Global Compact, 'The Ten Principles', 2000, available at www.globalcompact.com.

The company was acquired by L3 Communications in 2005 and given the name L3 Communications Titan Group.

Jake Sherman and Victoria DiDomenico, 'The Public Cost of Private Security in Afghanistan', Briefing Paper (New York: Center on International Cooperation, New York University, 2009), p. 7.

Committee on Armed Services, US Senate, note 195 above, pp. i-iv.

UN Office of Central Support Services, Procurement Division, 'List of Vendors on Provisional Status by Country of Origin', 4 November 2011, available at www.un.org/depts/ptd/pdf/ vendors.pdf.

UN Economic and Social Council, Commission on Human Rights, 'The Right of Peoples to SelfDetermination and Its Application to Peoples under Colonial or Alien Domination or Foreign Occupation', UN Doc. E/CN.4/1998/31, 27 January 1998.

Sarah Percy, Mercenaries: The History of a Norm in International Relations (New York: Oxford University Press, 2007), pp. 220-221. Ibid.

Victor-Yves Ghebali, 'The United Nations and Outsourcing Peacekeeping Operations', in Alan Bryden and Marina Caparini, Private Actors and Security Governance (Münster: LIT Verlag, 2006).

OHCHR, 'Private Security Companies Engaging in New Forms of Mercenary Activity, Says UN Working Group', 6 November 2007, available at www.ohchr.org/EN/NewsEvents/Pages/ DisplayNews.aspx? NewsID=5698\&LangID=E.

35 OHCHR, 'International Convention against the Recruitment, Use, Financing, and Training of Mercenaries', 2001, available at http://www2.ohchr.org/english/law/mercenaries.htm.

${ }^{236}$ UN Social and Economic Council, Commission on Human Rights, 'Use of Mercenaries as a Means of Violating Human Rights and Impeding the Exercise of the Right of Peoples to SelfDetermination', UN Doc. E/CN.4/2004/15, 24 December 2003, §42.

237 Resolution of the Human Rights Council on 'The use of mercenaries as a means of violating human rights and impeding the exercise of the right of peoples to self-determination', UN Doc. A/HRC/RES/10/11, 26 March 2009, § 13. 
OHCHR, 'Draft International Convention on the Regulation, Oversight and Monitoring of Private Military and Security Companies', 13 July 2009. Ibid., $\S 30$.

240 Resolution adopted by the Human Rights Council, UN Doc. A/HRC/RES/15/26, 7 October 2010 and the summary of the first session of the Open-ended intergovernmental working group to consider the possibility of elaborating an international regulatory framework on the regulation, monitoring and oversight of the activities of private military and security companies (Geneva: 23-27 May 2011), UN Doc. A/HRC/WG.10/1/CRP.2, §§29, 41, 43.

241 José L. Gomez del Prado, 'A Pyrrhic Victory at the United Nations over the 21st Century's "Privateer Industry"', unpublished manuscript, available at www.business-humanrights.org/ media/documents/gomez-del-prado-article-on-unhrc-resolution-on-pmscs-7-oct-2010.doc.

Ibid.

243 See note 240.

244 Michael Lipson, 'Peacekeeping: Organized Hypocrisy?', European Journal of International Relations, vol. 13, no. 1, 2007, pp. 5-34.

245 Wallenberg, note 88 above.

246 Department of Peacekeeping Operations and Department of Field Support, note 105 above, p. 28.

247 This has apparently been the case for the WHO. World Health Organization, 'Safety and Security for Staff and Premises and the Capital Master Plan', EB126/24 (Geneva: WHO, 19 November 2009). Brahimi, note 57 above, p. 60.

249 Leander and van Munster, note 209 above.

250 The code is a product of cooperation between the ICRC, the Swiss government and DCAF. Representatives from OCHA and the working group took part in discussions on the code, but did not present a common platform or a strong voice in favour of a code.

251 Cockayne, note 10 above, p. 3. 


\section{UN Use of Private Military and Security Companies: Practices and Policies}

\section{Åse Gilje Østensen}

The demands on UN delivery on the ground have massively increased since the 1990s in terms of scope, frequency and challenging environments. At the same time the UN system has increasingly paid private military and security companies (PMSCs) for a range of services in the areas of humanitarian affairs, peacebuilding and development support. While this practice may have serious consequences for the United Nations, it is subject to little discussion, not least because the issue is politically sensitive both within the United Nations and in many of its member states. Through an exploration of UN demand for private military and security services, this paper finds that a number of UN divisions buy a wide range of services which the organisation does not have the capacity or means to deliver. Hiring these companies is common within the UN system, and multiple perspectives on private military and security contracting coexist. However, these have rarely translated into coherent policies or guidelines that could guide UN organisations in setting standards for the companies or ensuring responsible contracting procedures. Instead, the UN approach to PMSCs is both opaque and incoherent. A more proactive, sensitive and deliberate political approach is needed in order to avoid the many pitfalls and risks associated with the involvement of PMSCs in the delivery of UN tasks.

Åse Gilje Østensen is a PhD candidate at the Department of Comparative Politics, University of Bergen, Norway. She is author of Outsourcing Peace? The United Nations' Use of Private Security and Military Companies (Saarbrücken: VDM Verlag, 2009), which this paper builds upon. Østensen takes a special interest in issues related to the role of private military and security companies in security governance processes. She served as a visiting researcher at the Geneva Centre for the Democratic Control of Armed Forces (DCAF) in 2010.

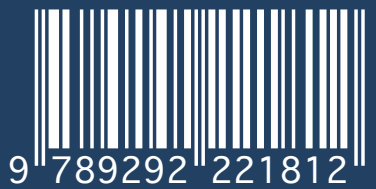

published by DCAF (Geneva Centre for the Democratic Control of Armed Forces)

PO Box 1361

1211 Geneva 1

Switzerland 